\title{
INTERDISCIPLINARNOST U HUMANISTIČKIM ZNANOSTIMA
}

\section{2. ožujka 2019.}

Vijećnica Filozofskog fakulteta u zagrebu

Davor Dukić: Dobra večer svima, hvala što ste došli na šesti po redu okrugli stol časopisa Umjetnost riječi. Tema večerašnjeg susreta je "Interdisciplinarnost u humanističkim znanostima" $i$ to je na neki način nastavak prošlog okruglog stola koji je održan relativno nedavno. Dakle, govorimo o godišnjim susretima, prošli je bio 8 . studenoga, u ovo doba dana i na ovome mjestu, a tema je bila "Kompetitivni projekti i humanistički studiji". Transkript tog okruglog stola objavljen je u broju 2/2018 Umjetnosti riječi. Jedna od pozvanih sudionica prošlog okruglog stola, inače članica uredništva Umjetnosti riječi, bila je kolegica Jasmina Vojvodić i ona je u uvodnom dijelu svog uvodnog izlaganja - dakle, bila je u poziciji u kojoj su danas kolege s moje lijeve strane - između ostaloga rekla i ovo, citiram nekoliko njezinih rečenica: "Ozbiljno držim da su humanističke znanosti, budući da se bave čovjekom i ljudskim vrijednostima i naglašavaju ljudske temelje svake spoznaje, temelj svih znanosti. I koliko god mi daleko zašli u proučavanje prirodnih znanosti, uvijek ćemo se vraćati temeljnim pitanjima. A ta pitanja rješava humanistika. Humanistika je fundamentalna znanost, a ove druge znanosti su zapravo nadgradnja. Medutim, svjesni smo da humanistika nema taj status koji bi zavređivala s obzirom na temeljna pitanja koja postavlja. To se već vidi na pragmatičnoj, financijskoj, budžetskoj razini." U drugom dijelu okruglog stola, na samom početku diskusije, a referirajući se na jednu rečenicu s kraja uvodnog izlaganja kolegice Morane Čale, koja glasi: "U našoj akademskoj zajednici književnost je zbilja Pepeljuga u filologiji", Tomislav Brlek rekao je sljedeće, malo duži citat: "Nešto mi je palo na pamet [smijeh] u vezi s tom metaforom o znanosti o književnosti kao Pepeljugi. Mislim da jedan važan dio krivice za to snosimo mi sami koji se time bavimo. Postoji prilično izražena tendencija u znanosti o književnosti zadnjih dvadeset, trideset, četrdeset godina da se bavi svime drugim osim književnošću, pa onda nije ni 
čudo da nikome nije jasno čime se bavi. Pritom naročito izbjegava objasniti zašto bi bavljenje književnošću bilo važno, a da to ne bude u terminima neke druge discipline. Dakle, to nije važno iz razloga koji bi bili i u sociološkoj, politološkoj, historiografskoj ili bilo kojoj drugoj disciplini, nego su to razlozi specifični samo za književnost. Ali tu vrstu odgovornosti znanost o književnosti odavno izbjegava preuzeti i stalno se pokušava prikazati kao nešto drugo. Pitanje je li humanistika fundamentalna je takoder pitanje koje se odavno izbjegava. Ona naprosto od početka priznaje da je inferiorna prirodnim znanostima i da jedino što joj preostaje jest da na neki način pokaže da i ona ima neko dodatno mjesto. Mislim doista, kao što ste svi i govorili, da bi stvari trebalo postaviti obrnuto: nije tako, nego je upravo suprotno.” Kraj citata.

Tomislav Brlek: Nemojte diskutirati, vidite što će vam se dogoditi. [smijeh]

Davor Dukić: Negdje između kritičko-optimistične tvrdnje o fundamentalnosti humanistike koju je izrekla kolegica Jasmina Vojvodić, 102 i s kojom se na kraju složio kolega Brlek, i njegove kritičko-pesimistične dijagnoze o samokrivici znanosti o književnosti i humanistike uopće za krizu identiteta i status u znanstvenoj zajednici smjestila se naša današnja, odnosno večerašnja tema ili problematika. U kratkom pozivu na ovaj okrugli stol napisali smo kako ćemo večeras raspravljati o tome što interdisciplinarnost jest, a što nije; koje su njezine specifičnosti, prednosti i zamke u humanističkim znanostima, napose u filologiji i znanosti o književnosti; imaju li domaće znanstveno-upravljačke institucije kapaciteta i senzibiliteta za procjenu i financiranje interdisciplinarnih istraživanja. Kao i obično, u prvome dijelu našeg druženja kraća izlaganja održat će pozvani sudionici. Predstavljam ih redom kojim će izlagati, dakle: Zrinka Blažević, Ivana Peruško Vindakijević, Tomislav Brlek i Milena Žic Fuchs. Zatim slijedi rasprava. Zrinka Blažević završila je studij povijesti i latinskog jezika s rimskom književnosti. Znanstvenu karijeru počela je na Hrvatskom institutu za povijest, a nastavila na Odsjeku za povijest Filozofskog fakulteta gdje predaje kolegije iz svjetske i nacionalne ranonovovjekovne povijesti. U svom istraživačkom radu nastoji spajati znanja i metode historijske i književne znanosti, a usto se bavi prevođenjem s latinskog. Najvažnije knjige: Ilirizam prije ilirizma iz 2008. i Prevodenje povijesti - teorijski obrati i suvremena historijska znanost iz 2014. Ivana Peruško Vindakijević završila je ruski jezik i književnost te hrvatski jezik i književnost na našem Fakultetu. 
Predaje na Katedri za rusku književnost Odsjeka za istočnoslavenske jezike i književnosti. Bavi se ruskom književnošću i kulturom 20. stoljeća te prevodi rusku prozu. Najvažnije knjige: Poetika progonstva - Gorkij i Bulgakov izmedu srpa i čekića iz 2013. i Od Oktobra do otpora - Mit o sovjetsko-jugoslavenskom bratstou u Hrvatskoj i Rusiji kroz književnost, karikaturu i film (1917. - 1991.), knjiga je izašla prošle godine. Već taj naslov upućuje na iskustva kolegice Peruško Vindakijević s ovom, nazovimo to - kao i u slučaju kolegice Blažević - unutarhumanističkom interdisciplinarnošću. Prikaz te knjige, koji je napisala prof. emerita Živa Benčić, nalazi se u ovom broju, 2/2018 Umjetnosti riječi. Tomislav Brlek završio je engleski jezik i književnost te španjolski jezik i književnost. Predaje na Odsjeku za komparativnu književnost, službeno na Katedri za opću povijest književnosti. Doktorirao je - to mi se isto čini dosta važnim, pa ću ovdje istaknuti - s temom T. S. Eliot u kontekstu suvremene književne teorije. Objavio je knjigu Lekcije: Studije o modernoj književnosti 2015. Milena Žic Fuchs, diplomirala engleski jezik i književnost te etnologiju. Predaje na Odsjeku za anglistiku našeg Fakulteta. Redovita je članica HAZU-a. Bila je ministrica znanosti i tehnologije od 1999. do 2000. godine. Članica je brojnih - kada bih nabrajao, potrošio bih ovaj uvodni dio - međunarodnih institucija vezanih uz znanost i upravljanje znanošću. Najvažnije knjige: Znanje o jeziku $i$ znanje o svijetu iz 1991, Kognitivna lingvistika i jezične strukture iz 2009. Zašto je ovdje? Pa prije svega zato što je uvela kognitivnu lingvistiku u domaću znanost. I onda kad govorimo o ovoj polidisciplinarnosti, njezino iskustvo interdisciplinarnih istraživanja u posljednje je vrijeme vezano uz istraživanje područja neuroznanosti. Dakle, za razliku od dviju kolegica ovdje već prelazimo granice humanistike. Ovim redoslijedom kako sam ih predstavio tako će naši gosti govoriti. Ja se više neću javljati do diskusije. Podij je njihov, prvo Zrinka.

Zrinka Blažević: Poštovane kolegice i kolege, poštovani kolega Dukiću, izuzetno mi je zadovoljstvo govoriti danas ovdje, ponajprije zbog toga što sam ovo svoje uvodno izlaganje osmislila kao svojevrsni hommage projektu kojega je voditelj bio Davor Dukić. Riječ je o projektu "Imagološka istraživanja hrvatske književnosti od 16. do 19. stoljeća". Naime, u sklopu toga projekta sam kao pozvani gost, povjesničar - dakle, članovi projekta su bili dominantno književni znanstvenici - tijekom sedam ili osam godina njegova trajanja pokušala osmisliti nešto što ću vam ovdje ukratko prikazati. Riječ je o svojevrsnoj ne inter-, nego transdisciplinarnoj platformi koja fuzionira rezultate književne imagologije s historijskom znanošću. S obzirom na to da je tijekom rada na projektu kulminirao i moj osobni interes za teoriju, pa tako i teoriju historije, 
ali i epistemologiju humanističkih znanosti, početni projekt povezivanja historijske znanosti sa znanošću o književnosti je zapravo nadrastao početni interdisciplinarni okvir. Dakle, riječ je o projektu koji sam prezentirala u nekoliko znanstvenih članaka i pokušavala promovirati na međunarodnim konferencijama i u kolegiju Historijska imagologija koji držim na diplomskom studiju povijesti. $\mathrm{Na}$ koncu, ovaj sam eksperiment pokušala artikulirati u prijedlog znanstvenoistraživačkoga projekta koji sam 2013. godine prijavila na poziv Hrvatske zaklade za znanost kao svojevrsni nastavak, proširenje književnoimagološkoga projekta koji je vodio kolega Dukić. S tom pričom ću i završiti ovo izlaganje upravo zato što mi se sudbina tog mog projektnog prijedloga zapravo čini vrlo ilustrativnom za stanje u hrvatskoj znanosti danas, odnosno za senzibilnost koju naša domaća znanstvena zajednica ima, odnosno nema za inter- ili, ako hoćete, transdisciplinarnost.

Dakle, ukratko ću vas upoznati s nekim načelima od kojih sam krenula osmišljavajući svoj projekt historijske imagologije. Moje temeljno polazište bio je transdisciplinarni okvir o kojem su znanstvenici različitih disciplina debatirali unutar rasprava o inter- i transdisciplinarnosti i koji se, barem meni, u tom trenutku učinio prikladnim za ono što sam s historijskom 104 imagologijom htjela polučiti. Vrlo kratko: danas su najveći zagovornici transdisciplinarnosti kao epistemološkoga pristupa u znanostima s jedne strane struja okupljena oko rumunjskoga fizičara Basaraba Nicolescua, a s druge tzv. Ciriška platforma koja okuplja znanstvenike različitih znanstvenih afilijacija oko tzv. Ciriške škole koja propagira nešto što se naziva postnormalnom znanošću, dakle znanošću koja pokušava na potpuno drugačijim temeljima osmisliti znanost onkraj one koju mi još uvijek u ovoj konzervativnoj disciplinarnoj paradigmi smatramo normalnom. Ne ulazeći sada u razlike između tih dviju struja, ovdje bih samo naglasila njihove konvergencije, koje sam i uzela kao polazište za razvijanje svoje vlastite transdisciplinarne paradigme historijske imagologije. Dakle, ono što dominantno obilježava transdisciplinarne pristupe danas jest stvaranje relevantnog i učinkovitog znanja. Pritom nije riječ o utilitarnosti u smislu korisnosti kakva recimo dominira u tehnologiji i prirodnim znanostima, već o znanju koje bi odgovorilo na, koliko god je moguće, sva relevantna pitanja iz domene onoga što se naziva svijetom života, odnosno Lebensweltom. Osim toga te nove kognitivne forme moraju zadovoljiti tri kriterija. Osim spoznajne moraju imati i praktičnu i moralnu vrijednost, što je važno podcrtati. I na koncu, temelj na kojemu je moguće graditi bilo koju transdisciplinarnu paradigmu je istraživačko pitanje koje je zapravo izvorište za definiranje teorijskih i metodoloških sredstava za njegovo rješavanje. Epistemološki 
okvir koji mi se činio prilično kompatibilnim s transdisciplinarnim pristupom je translacijska epistemologija, koja se danas također dosta promovira. Ovdje bih spomenula Genealogies of Knowledge, znanstveni skup koji će se održati 2020. u Hong Kongu upravo s ciljem razvoja mogućnosti translacijskih pristupa u znanostima koji zapravo, u najširem smislu riječi, potiču razmjene, adaptacije, modifikacije različitih teorijskih modela, heurističkih koncepata, metodoloških postupaka i promoviraju razmjenu između znanstvenih paradigmi i disciplina. Upravo zbog toga su travelling theories ili travelling concepts - putujuće teorije i koncepti - onaj temelj ili glavni katalizator koji omogućuje takav tip umrežavanja. Kada sam osmišljavala najširi mogući okvir unutar kojega bih smjestila svoj projekt historijske imagologije, morala sam se, dakako, vratiti na početak, odnosno na povijesne temelje imagološke subdiscipline, koja je proizašla iz znanosti o književnosti, točnije iz komparativne književnosti. Dakle, 50-ih godina se polako formira književna imagologija kao vrst ekstrinzičnog pristupa književnosti koja se bavi pitanjima kreiranja i reprezentacije različitih identifikacijskih modela, pri čemu je glavni naglasak na nacionalnim i etničkim stereotipima. Naime, u okviru književne imagologije u zadnjih 50-ak godina njena razvoja, posebice oko tzv. Aachenske škole - koju smo i mi u sklopu projekta kolege Dukića nastojali propagirati, promovirati i na neki način integrirati u hrvatske humanističke znanosti - kristaliziralo se nekoliko važnih istraživačkih tema i nosivih koncepata. Dakako, nosivi koncept je predodžba, odnosno image (engl.) ili image (fr.), ovisno o akademskoj sferi unutar koje se taj pojam u znanosti o književnosti koristio. Mi smo ga u sklopu našega projekta, koji je uključivao i prevođenje kanonskih radova iz područja književne imagologije, preveli kao predodžba. Ono što je bilo dominantno u dotadašnjim književnoimagološkim istraživanjima jest prvenstveno istraživanje etničkih i nacionalnih predodžbi u sklopu projekta, kako su ga francuski imagolozi nazvali, "Kako vidimo strane zemlje". Kad je riječ o epistemološkim pretpostavkama, književni imagolozi predodžbu dominantno tretiraju kao imagem, odnosno intertekstualni trop. Dakle, predodžbe u književnoimagološkom istraživanju postoje, najopćenitije govoreći, na razini teksta. E sada, meni se kao povjesničarki koja eksperimentira $s$ različitim disciplinama taj okvir učinio preuskim i zbog toga sam pokušala osmisliti nešto što sam nazvala historijskom imagologijom. U kojoj je mjeri historijska imagologija različita od književne? Ponajprije zato što je riječ o historijski kontekstualiziranim istraživanjima, dakle tu je predodžba u svome povijesnome kontekstu nastanka, odnosno distribucije i u konačnici recepcije ključna kao predmet istraživanja. $S$ druge strane, sam predmet 
istraživanja, dakle predodžbe koje su u književnoj imagologiji dominantno one etničke ili nacionalne, proširila sam na različite tipove predodžbi, koje osim etničkih ili nacionalnih mogu biti i kulturne, vjerske, rodne, ekonomske odnosno socijalne itd. Uz predodžbe kao predmet analize pokušala sam u taj projekt historijske imagologije uvrstiti i stereotipe u užem smislu riječi - dakle predodžbe koje su jednostavnije od ovih složenih književnih - i kategoriju mitova kao kompleksnije protopripovijesti koje funkcioniraju kao predodžba, ali je po svojoj konceptualnoj složenosti nadilaze. Dakle, kada sam osmislila, recimo to tako, istraživačke teme kojima bi se historijska imagologija mogla baviti, na koncu sam redefinirala i nosivi koncept, dakle koncept predodžbe, i to prilično široko. Predodžba u historijskoj imagologiji jest nešto što sam nazvala interferentnom konfiguracijom mentalnih slika, tekstualnih i ne-tekstualnih reprezentacija i oblika prakse. Praktički sve. Zašto mi se to učinilo zgodnim? Upravo zato što je u tako široko shvaćenom okviru onoga što predodžba jest ili što može biti moguće kombinirati ne samo pristupe znanosti o književnosti i historijske znanosti kao humanističke znanosti nego i pristupe prirodnih znanosti, poglavito neuroznanosti. To je nešto što je izazvano aktualnim neuroznanstvenim 106 obratom koji je prisutan u suvremenoj znanosti već desetak godina i to mi se učinilo primjerenim, poglavito kada je riječ o razumijevanju predodžbe kao mentalne slike. Upravo zato sam tako široko shvaćene predodžbe pokušala razumjeti hijastički, dakle s jedne strane kao antropološke univerzalije koje su ovisne o neurofiziologiji ljudskoga mozga, jer Antonio Damasio kaže da je zapravo ljudska kognitivna sposobnost primarno određena nečime što bismo mogli nazvati mišljenjem u slikama, a s druge strane kao fenomene koji su društveno i povijesno generirani, odnosno koji kao takvi utječu na formiranje društvenih i kulturnih imaginarija. E sada, kada čovjek pokušava osmisliti nekakav epistemološki model za takvu vrst ambicioznog istraživanja koje počiva na ambiciozno definiranome pojmu predodžbe, onda se treba na neki način uteći najširem mogućem okviru, koji sam, opet oslanjajući se na čitanja različitih teoretičara i filozofa znanosti, nazvala postkonstruktivističkim diskurzivnim materijalizmom. Zvuči, naravno, izuzetno pompozno, ali u bazi toga jest s jedne strane neofenomenološki pristup koji polazi od pretpostavke da su povijesni akteri, dakako, određeni društvenom i kulturnom strukturom unutar koje žive, ali su ujedno i aktivni kreatori i resignifikatori naslijeđenih kulturnih shema koje, naravno, ovise o njihovom tjelesno definiranom i određenom iskustvu stvarnosti. S druge strane taj je pristup određen neurosemantičkom metodologijom koja zapravo polazi od neuroznanstvene pretpostavke o izomorfiji ljudskoga mozga, što 
znači da svi pojedinci unutar neke kulturne grupe posjeduju koliko-toliko dijeljenu kognitivnu mapu.

$\mathrm{Na}$ koncu, polazeći od književnih izvora kojima se bavi književna imagologija, pokušala sam proširiti okvir onoga čime bi se, u smislu izvora na kojima bi radila, mogla baviti historijska imagologija tako da sam uz različite tipove i žanrove tekstualnih izvora tu uključila vizualne izvore, ali i tjelesne i kulturalne prakse koje su, naravno, direktno povezane s ovom neuroznanstvenom, odnosno biologističko-materijalističkom komponentom koja mi se u mom imaginarnom projektu historijske imagologije učinila zgodnom. Kada je riječ o mogućim znanstvenim polazištima, znanstvenim disciplinama na kojima bi se taj projekt mogao temeljiti, krenula sam od neuroznanosti, psihoanalitičke teorije i socijalne psihologije koje s jedne strane mogu objasniti, nazovimo to metaforički tako, procese kreiranja slika u glavama, a s druge strane mogu objasniti funkcije predodžbi u smislu kognitivnih orijentira koje posjeduju svi pojedinci i grupe. Osim toga historijska se imagologija kao historijski kontekstualizirano istraživanje predodžbi prirodno povezuje s historijskom znanosti sa svim njezinim potencijalno korisnim subdisciplinama koje bi mogle pomoći historijskoj imagologiji u detektiranju povijesnih kontinuiteta i promjena u proizvodnji, upotrebi i funkcijama predodžbi. Usto, učinilo mi se prikladnim uključiti i neke od rezultata koji su devedesetih godina bili generirani unutar postkolonijalne teorije, posebice kada je riječ o mehanizmima transkulturne cirkulacije predodžbi, odnosno o hibridizacijama i sinkretizmima koji nastaju kao posljedica takvih procesa. Nadalje, s obzirom na to da sam u potencijalni skup mogućih izvora za historijskoimagološka istraživanja uključila i slike, učinilo mi se korisnim uteći se intermedijalnim i vizualnim studijima koji zapravo pokušavaju detektirati s jedne strane kakvu funkciju ima vizualno, odnosno slike u procesu proizvodnje značenja, a s druge strane kako slike kao takve sudjeluju u procesu komunikacije. $\mathrm{Na}$ koncu sam upravo na temelju potonjih dviju paradigmi osmislila metodološki model koji sam nazvala transkulturnom komparativnom semantikom slika koja prati kako se slike u suvremenome društvu globalne hiperprodukcije slika - kako onih vizualnih tako i onih tekstualnih - zgušnjavaju, na koji način se distribuiraju i, u konačnici, kako su povezane s odnosima moći. I naposljetku 2013. godine napisala sam projekt - tada se još pisao samo na engleskome, prije nego što smo se izborili da se piše i na hrvatskome jeziku - koji sam nazvala Entangled images: Social and cultural images in premodern and modern period. U prijedlogu tog projekta bilo je sumirano sve ono što sam maloprije ukratko izložila. Kakav je bio rezultat? Dobila sam jednu polupozitivnu i jednu negativnu 
recenziju, a negativna recenzija, koja je bila na engleskom jeziku, počinjala je sljedećom rečenicom: ja sam tradicionalni povjesničar i od svega ovoga ne razumijem niti riječ. Hvala lijepa.

Milena Žic Fuchs: Mi bismo trebale surađivati jer ovo o čemu ste vi sada govorili u jednome je segmentu dio istraživanja koja radim u Institutu za mozak. Prof. Judaš i ja smo na Zakladi prijavili multidisciplinarni projekt. Potka je da smo uzeli kineski, arapski, hrvatski i engleski - dakle jezike s vrlo različitim jezičnim strukturama. Meni su, doduše, čelni ljudi Zaklade rekli da to ne prijavljujem jer je multidisciplinarno. Ali dobro, Judaš i ja smo odlučili da vrijedi pokušati jer taj problem treba konceptualizirati. Kako je naš projekt završio? Dobili smo dvije recenzije. Ne treba niti isticati da su dvije recenzije za takav projekat premalo. Ja sam predsjedala elitnim panelom ERC-ja Human mind and its complexity. Kod takvih se projekata tražilo šest do deset recenzija. To je bio prosjek. Vi ste rekli jedna polupozitivna i jedna negativna? Naše recenzije su završile ovako: da nitko nigdje na svijetu nije radio takvo istraživanje. A onda, jedno od sljedećih pitanja je glasilo, imate li objavljenih radova na navedenu temu? Dakako da smo dobili nula bodova,

108 ali recenzentima nije palo na pamet da su uvodu svojih recenzija napisali da to nitko nije radio i dakako da nismo mogli imati objavljenih radova. To nema nigdje. Tako da dijelimo istu sudbu. [smijeh]

Ivana Peruško Vindakijević: Dobra večer još jednom. Moje se izlaganje zapravo sastoji od dva dijela. Premda sam ovdje primarno pozvana kao autorica knjige Od Oktobra do otpora: Mit o sovjetsko-jugoslavenskom bratstvu u Hrvatskoj i Rusiji kroz književnost, karikaturu ifilm (1917.-1991.), odlučila sam malo modificirati svoju prvotnu zamisao. Manje bih govorila o sebi i svojoj knjizi, hoću nešto i o tome, ali čisto na razini koncepata, nikako na razini kako, zašto, što sam sve obuhvatila. Ja sam čak naslovila svoje dvodijelno izlaganje i u tom smislu pročitat ću vam naslov prvog dijela u kojem prepričavam vrlo radikalne - pri čemu kažem da nisam odvjetnik čovjeka koji zagovara te stavove - ali jako zanimljive stavove koje sam sažela ovako: "Jesmo li spremni za radikalnu projekciju humanističkih znanosti?" Drugi je naslov puno manje ambiciozan i radikalan i ima veze sa mnom i mojom knjigom i upravo zbog toga glasi "Pokušaj dijaloga", koji sam zagovarala u svojoj knjizi.

Počet ću s prvim i počet ću ga citatom: "Zamislite da postoje fizika, kemija, biologija i druge temeljne znanosti, samo bez tehnologije koja ih podupire. Zamislite da nema automobila i zrakoplova. Nema agronomije, 
nema inženjerskih ni graditeljskih profesija. Sve što postoji tek je izučavanje prirode, ali ne i njezino preoblikovanje. Upravo je takvo današnje stanje u humanističkim znanostima. One izučavaju čovjeka i sve sfere kulturne djelatnosti, ali su pritom pasivne. Nemaju vlastitih tehnologija, ali s drugog rakursa. One izučavaju stvaralaštvo, a da pritom same ništa ne stvaraju." Tako otvara svoju impozantnu knjigu od nekih petstotinjak stranica, koju, bit ću iskrena, nisam pročitala do kraja, ali veći dio jesam, čovjek koji je vama vjerojatno nepoznat, rusistima je itekako poznat, zove se Mihail Èpštejn. On je rusko-američki filozof, filolog, profesor ruske književnosti i kulturne teorije. Isto tako čini mi se da je važno spomenuti da je direktor Centra za humanističke inovacije u Velikoj Britaniji. Osnovni (Ëp̌tejnovi) koncepti koji su me zaintrigirali i koje ću danas pokušati predstaviti sadržani su u knjizi koja je na ruskom naslovljena, čisto da čujete, Ot znanija $k$ tvorčestvu. Kak gumanitarnye nauki mogut izmenjat' mir. U prijevodu bi bilo Od znanja do stvaralaštva: kako bumanisticke znanosti mogu promijeniti svijet. Probat ću reći nešto o Èpštejnu i njegovim specijalnostima, da uopće steknete dojam. Èpštejn je vrlo minuciozan filolog, ali isto tako vrlo radikalan i vrlo hrabar inovator. Bavi se kulturnom i književnom teorijom, izučavanjem novih metoda, a zanima ga i, zbog čega mi se čini da je jako zanimljiv - nažalost, ne možemo ga imati ovdje, ali zadovoljit ćete se sa mnom kao nekime tko ga čita i pokušava predstaviti - interdisciplinarni pristup u humanistici. Zanimaju ga, osim toga, filozofija, poetika postmodernizma, zbog čega je nama, mislim rusistima, osobito dragocjen, povijest ruske književnosti itd. Ova njegova knjiga objavljena je 2016. godine na ruskom jeziku, ali mislim da će imati i englesko izdanje. Inače piše i na ruskom i na engleskom jeziku. Knjiga je upravo rezultat dugogodišnjih ovdje ne govorimo o pet, nego o deset i više godina - interdisciplinarnih istraživanja. Cilj i zadaća su vrlo osebujni i pragmatični. Pročitat ću vam: pronaći izlaz iz krize humanističkih znanosti, odnosno dokinuti izolaciju u kojoj se humanističke znanosti već dosta dugo nalaze. Što zanima Èpštejna? Njega zanimaju mogući putevi humanističkog stvaralaštva, putevi mašte u znanosti, ali isto tako i stvaralačkih inovacija. Knjiga ima osam poglavlja, bavi se filozofijom, kulturologijom, lingvistikom, znanošću o književnosti, ali isto tako i jednom zanimljivom granom, a to je pitanje autorstva, odnosno intelektualnog vlasništva. Gdje on vidi spas od krize u kojoj se trenutno nalazimo, jesmo li mi sami krivi za tu krizu i kako dokinuti izoliranost humanističkih znanosti? Ni manje ni više, drži Èpštejn, nego u digitalnom svijetu -, odnosno u elektroničkim sadržajima. Digitalni svijet i mogućnosti koje nam on pruža naziva riznicom kulturnih, ali i znanstvenih informacija. 
Upravo u digitalnim svjetovima, odnosno sadržaju koji nam nudi internet on vidi prostor za konstruktivno promišljanje i razmišljanje. Mislim da je sasvim očigledno zbog čega. Internet naprosto olakšava i ubrzava rad humanističkim znanostima. On je u svojoj knjizi dao jako puno primjera ljudi koji su godinama ručno radili stvari koje mi danas, uključujući i mene samu - kada sam imala problema s arhivima, materijalima itd. - nevjerojatnom brzinom postižemo preko interneta. Èpštejnova knjiga je pokušaj konstruktivnog humanističkog razmišljanja na koje ja osobno nisam naučena, a vjerojatno nije ni većina vas. Njegov koncept u nekim je trenucima odbojan, a u nekim vrlo privlačan. To konstruktivno razmišljanje kod njega obuhvaća nekoliko različitih razina. Recimo, ide od jezičnih mikrorazina pa sve do predlaganja posve novih disciplina, konceptualnih sustava, metoda ili pak novih žanrova intelektualnoga stvaralaštva. Što zamjera nama, pa i sebi, tj. humanističkim znanostima? Pasivnost. Ukratko, zamjera nam nedovoljno inicijative, $i$ to nedovoljno inicijative s dovoljno širokim civilizacijskim potencijalom. Sljedeće što nam zamjera, što možemo često čuti, a čut ćemo vjerojatno i danas, to je nedostatak praktičnosti. Odnosno Èpštejn humanističkim znanostima zamjera činjenicu da ne mare za praktični re110 zultat svojih istraživanja i u tom vidi svoju zadaću: stvaranje novih disciplina, novih formata kulture na osnovi analiza i podizanje nekih novih razina. On se pita sljedeće, citiram: "Zašto se humanističkim znanostima, odnosno filolozima, filozofima i drugima uskraćuje pravo da sudjeluju u stvaranju jezika i kulture?" Evo vam nekoliko praktičnih primjera njegovih novih humanističkih disciplina. Èpštejn predlaže postojanje skriptologije. Skriptologija bi bila grana koja se bavi homo scriptorom, odnosno čovjekom koji piše. Epštejn ne vidi razloga zašto ne bi postojala tehnohumanistika ili ekohumanistika koja bi se bavila čovjekom kao tvorcem tehnosfere. Èpštejn zagovara horologiju, odnosno disciplinu koja bi se bavila mehanizmima samouništavanja civilizacije, ali isto tako i mehanizmima njena očuvanja, odnosno opstanka. I na koncu predlaže postojanje kulturonike, odnosno discipline koja bi imala zadaću stvaranja novih kulturnih vrijednosti i novih kulturnih institucija. Zvuči čudno. Što je činiti, u konačnici, humanističkim znanostima? Izdvojila sam četiri praktična koncepta koji se bave odnosom između otkrivanja i proučavanja. Često citira Mihaila Bahtina i njegovu tezu da sve počinje na shvaćanju, odnosno razumijevanju teksta, čovjeka, okoline itd. On se s tim slaže, ali ide i korak dalje i kaže da treba prebaciti naglasak na otkrivanje, a ne ostajati permanentno na analizi, odnosno proučavanju. $\mathrm{U}$ tom smislu predlaže prelazak s analize na sintezu koja je imanentna prirodnim disciplinama, što je nama nešto teže ili naprosto na 
to nismo naviknuti. Da preživimo krizu humanističkih znanosti, svi znamo da moramo proći kroz nekakvu dubinsku reformaciju i nanovo osmisliti svoje ciljeve, što je možda i najteže. On kaže da se humanističke znanosti moraju integrirati u duhovni, ali isto tako i u znanstveno-tehnološki razvoj svijeta, koji one uporno negiraju. Budući da ima petsto stranica i bavi se vrlo zanimljivim konceptima, od filozofije do znanosti o književnosti, ja ću sada ipak proći samo mali dio onoga što on predlaže kada je u pitanju znanost o književnosti, kojom se i ja u konačnici bavim. Na osnovi ovoga što ste dosad čuli i sami shvaćate koliko je radikalan. Jednako je radikalan, ako ne i više, kada je u pitanju znanost o književnosti. Posvećuje joj sedmo, pretposljednje poglavlje i postavlja stvari ovako: trenutno znanost o književnosti čine teorija književnosti, književna kritika i povijest književnosti. On ne vidi razloga zašto joj ne bismo dodali jednu novu, eksperimentalnu disciplinu koja bi bila sastavni dio eksperimentalne znanosti o književnosti i kaže sljedeće: ako je književna teorija usmjerena k vječnome, ako je književna kritika usmjerena k sadašnjosti te, isto tako, ako je povijest književnosti usmjerena k prošlosti, nama treba spona s budućnosti, nama treba budućnost. On tu budućnost i disciplinu vidi u terminima kao što su prognostika ili kreatorika. Dakle, posve eksperimentalna znanost o književnosti. Èpštejnova teorija pretpostavlja i destabilizaciju teksta. To mi je naročito zanimljivo i mislim da je za nas jako važno. Možda samo da objasnim što misli kada kaže prognostika, kreatorika. Naime, on smatra da bismo se mi trebali odmaknuti od poetike i estetike $\mathrm{k}$ transpoetici i transestetici, odnosno $\mathrm{k}$ nekakvim novim mogućnostima. Što se tiče destabilizacije teksta, kaže da je klasično poimanje teksta, koje je svima nama važno i temeljno, centralno mjesto humanističkih znanosti, pretpostavljalo vrlo stabilnog materijalnog nositelja. Taj stabilni materijalni nositelj je papir ili u konačnici knjiga. Danas su se stvari radikalno izmijenile. Danas taj nositelj više nije tako stabilan i postoji u elektroničkom obliku. Èpštejn taj elektronički tekst naziva tekstoidom, dakle tekst koji više nije fiksiran i stoga je zapravo tekstoidan. Zbog svega navedenog Èpštejn predlaže i novu tipologiju tekstualnih formacija, pa ćemo u njegovoj knjizi naići na posve nov metajezik, odnosno termine kao što su tekstoid, nadtekst, sintekst i mnogi drugi. Što oni rade? Oni preobražavaju, transformiraju naše, uvjetno rečeno, tradicionalno poimanje ne samo teksta nego i književnosti, odnosno umjetnosti riječi.

Moram reći i ovo, premda je škakljivo. Èpštejn i u svojem članku i u knjizi zamjera akademskim časopisima uskogrudnost, odnosno shematizam. Zamjera im što svi članci počinju nalikovati jedni na druge te se pita postoje li na svijetu akademski časopisi koji objavljuju takozvane drske ideje, odnosno 
one koje su izazov znanstvenim konvencijama, i kako se s time nositi, gdje naći mjesta za njih? Èpštejn se dotiče i bolnog procesa recenziranja koje s jedne strane osigurava visoku profesionalnu razinu publikacije, ali istovremeno širi i potiče, po Èpštejnovu mišljenju, intelektualni konformizam i prosječnost, odnosno osrednjost. Meni je taj teoretičar važan zbog zadaća koje je definirao, naprosto bacio pred nas. Jedna od njih je ne samo stvaranje novih tekstova nego i širenje konteksta. A drugu od njih smatram jako važnom. On vidi zadaću humanističkih znanosti, pročitat ću, u tome da "prepoznaju humanističko ondje gdje se prije pokazivalo samo znanstveno, samo tehničko i samo političko", za što mislim da je izuzetno važno. Nije pesimističan. Premda misli da živimo u dubokoj krizi, on vidi poeziju - kojoj je posvetio jako puno stranica ove knjige - i u tehnologiji, na internetu, u biologiji, ondje gdje je mi tradicionalno ne bismo vidjeli.

$\mathrm{Na}$ tom tragu pronalaska humanističkoga u vulgarnom, ako politiku smatramo vulgarnom, nastojala sam oblikovati svoju knjigu Od Oktobra do otpora i nazvala je pokušaj dijaloga. Ona je nastala iz želje da se vulgarna politika sovjetsko-jugoslavenskih odnosa izučava zapravo iz humanističke perspektive, baš kao i Èpštejn, koji je posvetio cijelo poglavlje poeziji, za koju 112 tvrdi da može imati nevjerojatan utjecaj na sudbinu civilizacija - s time da ja nisam bila tako prepotentna, moje su želje bile puno skromnije. Ono što sam zapravo htjela u svojoj knjizi jest pokazati utjecaj književnosti, filma i nekih vizualnih umjetnosti na sudbinu jednog geopolitičkog odnosa. Pokušala sam istražiti utjecaj političkoga na humanističko. Ne znam koliko je taj dijalog uspješan, ali evo, to su bila moja nastojanja. Nisam imala projekt, ali ova knjiga se pisala jako dugo i rezultat je bar petogodišnjih, a možda i dužih što arhivskih što teorijskih - istraživanja. Teorijsko polazište je bila trajna opsesija Mihailom Bahtinom, odnosno onim što što on naziva dijalogičnošću kultura, što sam zapravo htjela pokazati ovom knjigom, odnosno uspostaviti potreban dijalog u istraživanju onoga što je Burke svojevremeno nazvao polifoničnom poviješću, i to na primjeru jednog dijaloga. Taj dijalog su vodile ruska i hrvatska kultura i u tom segmentu morala sam suziti svoja nastojanja: na književnost, film i one segmente kulture za koje sam se smatrala više-manje kompetentnom. Upravo je zbog toga taj dijalog težio nekakvoj, kako smo prije rekli, unutarnjoj disciplinarnosti, odnosno moja osobna želja i zadaća bila je osvijetliti međuprožimanje, tako da sam ovdje sklona razgovarati o konceptima kao što je kulturni transfer, ali isto tako književna adaptacija i ini koncepti. Svi znamo da koncepti, književne teme, sižei i slično putuju iz jedne nacionalne kulture u drugu, iz jedne nacionalne književnosti u drugu. Mene je zanimao taj transfer, taj put iz 
Rusije u Hrvatsku, iz Hrvatske u Rusiju pod a), a pod b) na tragu imagologije zanimao me i taj mit. Zanimao me mit o slavenskoj duši, mit o sovjetskojugoslavenskom, konkretno rusko-hrvatskom - premda se kao rusko-hrvatski nikada nije identificirao, ali kao sovjetsko-jugoslavenski bome jest - dakle mit o sovjetsko-jugoslavenskom bratstvu i što se s njim dogodilo. Za takav koncept, projekt ili knjigu književnost nije bila dovoljna. Književnost mi je bila samo polazište, točka u kojoj sam našla mnogo, ali nisam našla dovoljno. Projekt je, osim toga, bio zamišljen mnogo šire. Mislila sam istraživati i u Beogradu i u Sarajevu i uključiti cijeli jugoslavenski imaginarij, a bila sam i dosta ambiciozna u kronološkim odrednicama svoje knjige, koja kreće od 1917. godine i završava 1991. godine, znamo svi zašto. Ubrzo sam shvatila da moram suziti svoje želje i nastojanja te ih svesti na rusko-hrvatske odnose. Dat ću vam svega nekoliko primjera. Čime sam se bavila i zbog čega smatram da je ta knjiga trebala biti napisana? Možemo razgovarati je li ili nije dobra, ali mislim da je prva takva knjiga, prvi pokušaj takvog dijaloga. Navest ću vam koncepte koji su me zanimali i koje sam obrađivala u knjizi, a tiču se književnosti. Socrealizam u hrvatskoj književnosti je koncept koji smo posudili i uvezli iz Sovjetskog Saveza. Zanimala su me sljedeća pitanja: kako se on adaptirao, ako se uopće adaptirao? Je li postojao u onom obliku u kojem je postojao u Rusiji? Da odgovorim na to pitanje, naravno, moram napisati kako je postojao u Rusiji. Ili se dogodilo nešto prekrasno, a to je da se preobrazio - često se to dogodi - u nešto treće, na primjer. Sljedeći koncept koji me zanimao: što se događalo s usvojenim tudim konceptima za koje nikada nismo rekli da su tuđi koncepti? Što se događa s, primjerice, filmom koji mi baštinimo kao naš prvi partizanski film o jugoslavenskim partizanima i Titu, a snimio ga je ruski redatelj s ruskom ekipom na ruskom jeziku, i to u maniri klasičnog socijalističkog ruskog filma sovjetskoga vremena? Zanimalo me je jesu li odjeci ruske kulture u književnosti, arhitekturi, likovnoj umjetnosti, filmu - ovdje postoji jako puno ljudi kojima bih trebala zahvaliti, s kojima sam razgovarala i čije sam radove o temama koje slabo poznajem čitala, primjerice o povijesti arhitekture, likovne umjetnosti itd. - dakle jesu li odjeci ruske kulture u nas adaptirani, jesu li se asimilirali bez obzira na politički diktat, odnosno bez obzira na izmjenjivanje filije i fobije ili njemu usprkos? Zašto me to sve zanimalo? Pa s obzirom na netrpeljivost koju sam i sama osjetila u nas, koja se u devedesetim godinama odnosila na sve što je rusko, te na sindrom amnezije koju smo imali neko vrijeme, na činjenicu da se nismo suočavali s vlastitom prošlosti u trenutku kada je ruska znanost o književnosti već imala nešto što se zove sovjetologija, dakle, činilo mi se važnim uspostaviti dijalog između navedenih kultura, imajući 
pritom u vidu dva koncepta. Jurij Tinjanov ih je svojevremeno razradio. Prvi je dijalog i odnos između centra i periferije. Zanimalo me mijenjaju li centar i periferija svoje odnose i kako se oni razvijaju. Svi znamo da je 1917. godine centar bio Sovjetski Savez. U kojem trenutku smo mi postali periferija? Jesmo li možda u nekom trenutku mi pak postali centar od kojega su oni crpili? Drugi koncept sam posudila iz traduktologije, a to je koncept primarnih i sekundarnih kultura, način na koji one perpetuiraju u vremenu, da bih u konačnici samoj sebi mogla odgovoriti na neka pitanja. Poticaj za ta pitanja došao mi je iz književnosti, od Miroslava Krleže koji je u Izletu u Rusiji rekao: Ostavit ću sve, pljujem na ovu zemlju i odlazim u Rusiju jer smo mi zapravo samo periferija, odnosno provincija. Hvala.

Tomislav Brlek: Ovo uopće neće biti tako uzbudljivo, bit će, naprotiv, skoro pa sve suprotno. [smijeh] Bit će svakako starije, skromnije, sporije. Kada je već Davor spomenuo Eliota, u tom smislu bi se mogla citirati fraza iz jednog njegovog pisma: nitko nije toliko radikalan da bude konzervativan. Ja mislim da je problem humanistike baš suprotan od toga što misli Èpštejn. Nisam čitao tu knjigu, ali sam čitao neke njegove ranije knjige. Zadržat ću

114 se na proučavanju književnosti, ali čini mi se da s malim modifikacijama to vrijedi za humanistiku općenito - mada, naravno, nemam pretenzija da donosim sudove o drugim dijelovima humanistike - a to je da mi zapravo uopće ne znamo ni to što znamo i zbog toga stalno proizvodimo ovakve i onakve obrate, uvodimo ovakve i onakve metodološke i terminološke inovacije i tome slično. Recimo, sve što Èpštejn tvrdi, sve je to karakteristično za svaki od takvih momenata kad jedan ili više autora odluče prezentirati neki novi pristup za koji ili sami smisle ime ili mu netko drugi prida nekakav naziv pa onda sami objašnjavaju u čemu je razlika između njihovih pristupa i onoga što se radilo do tada. Tu se uvijek uspostavlja, kako to Derrida upravo tim povodom kaže, divlja, odnosno nasilna, periodizacija, gdje se sve radikalno dijeli na ono prije i ovo sad, s time da se onome prije, naravno, pripisuju različite negativne karakteristike, koje će sad ovaj naš novi pristup, dakako, popraviti, ispraviti, riješiti i slično. Recimo, postojanost teksta. Tekst, naravno, nije bio postojan ni kada je bio papirnat, a naročito ne prije toga, kad je bio usmen, pa dakle nije bilo materijalnog nositelja. I kad ga je imao, kad je bio štampan na papiru, postojala su u najmanju ruku različita izdanja. $\mathrm{Pa}$ čak i da nađemo kakav primjer, malo vjerojatan, teksta koji je ostao postojan u svom materijalnom obliku kroz neko dulje razdoblje, interpretacije toga teksta na bilo kojoj razini, od onih uredničkih do kritičkih, a nadasve čitateljskih i književnopovijesnih, toliko su različite da se o postojanosti teksta 
uopće ne može govoriti. Dakle, postojanost teksta je mit. Naravno, taj je mit Èpštejnu potreban da bi afirmirao svoju suprotnu poziciju. To je jedna stvar. Druga stvar je to da svako problemsko područje zahtijeva posebnu disciplinu koja se tvori tako da se tom problemu doda sufiks -logija. Zašto bi bilo koje problemsko područje zahtijevalo posebnu disciplinu? Zašto se ne bi bilo kojim od tih problema, koji su svi, naravno, sami po sebi relevantni, moglo baviti u okvirima postojećih disciplina? Naravno, ako ti disciplinarni okviri nisu tako strogi kao u slučaju tih recenzenata koji ne razumiju nešto što bi trebalo spadati u područje njihove kompetencije. Netko tako kaže da je konzervativni povjesničar i da to ne razumije, ali projekt je historiografski sasvim neovisno o nečijim teorijskim ili metodološkim sklonostima. Predmet istraživanja je ipak, dakle, u nadležnosti tog recenzenta.

Što se tiče brzine - rekao sam da ću se ja zalagati za sporost. To mi se uvijek činilo kao jako zgodna metafora. U romanu Umberta Eca Il pendolo di Foucault ima jedna epizoda kada tri glavna lika nabave kompjutor, a jedan od njihovih glavnih projekata je da permutacijama slova koja tvore riječ Jahve dođu do tajnog imena Boga. Tih je kombinacija i mogućnosti jako mnogo i zato kupe kompjutor da bi napravili algoritam koji će neusporedivo brže riješiti taj problem. Dvojica su oduševljena, dok treći kaže da je to potpuno promašeno, uopće nije stvar u tome da dobijemo rezultat, stvar je u tome da mi rukom ispisujemo sve te hiljade, a zapravo možda i milijune imena. Onda još objašnjava da brojčane vrijednosti hebrejskih konsonanata i vokala broj imena čine više-manje beskonačnim. Uopće nije poanta da se dođe do tajnog imena Boga, poanta prosvjetljenja je u procesu, ne u rezultatu. To je jedno. Drugo, što se tiče inovacija. Cardinal Newman u svojoj raspravi The Idea of a University vrlo lijepo formulira temeljnu zamisao da univerzitet ili sveučilište nije mjesto gdje se rađaju pjesnici ili besmrtni autori, utemeljitelji škola, vođe kolonija, osvajači. Ne obećava generaciju Aristotela, Newtona, Napoleona, Washingtona, Rafaela ili Shakespearea, iako su se takva čuda prirode ponekad znala naći i unutar zidova sveučilišta. S druge strane, sveučilište nije zadovoljno time da oblikuje eksperimentalista (misli se na proučavatelja prirodnih znanosti), ekonomista ili graditelja, iako i takvi spadaju u njegovu nadležnost. $\mathrm{Ne}$, sveučilište je mjesto gdje se vrlo običnim sredstvima dovodi do vrlo običnog cilja, a to je da se digne intelektualna razina društva, da se kultivira javni um ili javnost, da se pročisti - u smislu da se makne višak - i širi znanje. Sveučilište mora, dakle, sebi postaviti mnogo skromnije ciljeve nego što se obično može čuti. Cilj sveučilišta ne može biti da svake godine dobije Nobelovu nagradu za ovo i ono. Sveučilište je mjesto gdje se nešto održava. Ako u sklopu tog sveučilišta postoji ovaj ili onaj eksperimentalni 
centar, naravno da će oni možda povremeno nešto takvo postići, ali to ne bi trebalo biti glavni zadatak. Uglavnom, to bi bilo uvodno.

Ono što sam zapravo htio reći tiče se veze između književnosti i lingvistike koja bi trebala biti prirodna jer se radi o dvjema - pod književnošću mislim, naime, na proučavanje književnosti - disciplinama ili područjima koji se bave istom stvari, a to je jezik, i koja je veza, dapače, i teorijski odavno utemeljena, pa ipak to nikakvih naročitih posljedica na proučavanje književnosti u zadnjih četrdeset ili pedeset godina nije imalo, osim jednog područja koje ću kasnije spomenuti. To teorijsko utemeljenje dao je Jakobson u tekstu Poetika i lingvistika, ali, ponovit ću, to je ostalo bez većih posljedica. Ako su proučavanje književnosti i lingvistika, kao što svi znate iz svojih iskustava na filološkim katedrama, toliko udaljeni a tako su srodni, pa kako bi se onda mogle povezivati i mnogo udaljenije discipline? Mislim da problem leži negdje drugdje, ne u našoj želji da se povezujemo ili ne. To je jedna stvar. Druga stvar se tiče toga da svaki problem traži svoju posebnu disciplinu. U tom smislu mi se čini ilustrativnom jedna anegdota: kada je Vatroslavu Jagiću jedan njegov doktorand na pitanje čime se namjerava baviti poslije doktorata odgovorio da se misli baviti bohemistikom, rekao mu je: $\mathrm{Pa}$ šta 116 je vama, to ne postoji, postoji samo slavistika. Naravno da to ne znači da je Jagić mislio da ne postoje Česi ili Slovaci, češka ili slovačka kultura, ili štogod slično - mislio je da ti problemi mogu biti obuhvaćeni slavističkom perspektivom. Dakako, već u to vrijeme Pavle Popović je za Jagića rekao da je živi anakronizam jer zna sve slavenske jezike, a za tim više nema potrebe jer sad dolazi vrijeme nacionalnih filologija, sad ce se svatko od nas baviti svojim zasebnim disciplinarnim područjem. Ako se disciplina shvati na takav način kako ju je shvaćao Popović, onda je očito potrebno da svako problemsko područje ima svoju disciplinu i svoju -logiju, ali je isto tako očito da se te discipline neće moći po prirodi stvari naći na nekom zajedničkom projektu - baš zato što svaka svoj raison d'être nalazi u tome da je nespojiva s nečim drugim. S druge strane, disciplina se može shvatiti onako kako je Jagić shvaćao slavistiku. Da to nije nipošto nesavladiv cilj, dokazuje činjenica da je Jagić dok je radio na srednjoj školi napisao srednjoškolski udžbenik staroslavenske gramatike od šezdesetak stranica, koji je smatrao primjerenim gimnazijalcima ne zato što će se baviti paleografijom, nego zato što im daje osnovu da kasnije relativno lako svladaju sve slavenske jezike. Kada sam ga o tome pitao, profesor Damjanović mi je rekao da bi bio više nego zadovoljan kad bi njegovi postdiplomanti danas znali to što piše u tom udžbeniku, da imaju razinu znanja koju je prije sto pedeset godina Jagić mogao tražiti od svojih gimnazijalaca, i to - vrijedi posebno istaći - ovdje, u Zagrebu. 
Drugo, u vezi s onim što je staro i što je novo, što je praktično i što nije praktično. $U$ tom smislu mislim da je u pravu s jedne strane Eliot, a s druge strane Trocki, koji su tvrdili istu stvar, a to je da iako književnost ima posljedica izvan književnog područja i iako su te posljedice ono što ta književna djela čini društveno relevantnima, prvo treba ustanoviti jesu li ona uopće književna djela. To kaže Eliot, dok potpuno isto kaže i Trocki u vezi s proleterskom književnosti. Naime: loši stihovi mogu biti društveno simptomatični, ali ne stvaraju proletersku poeziju jer ne stvaraju nikakvu poeziju. Što se pak tiče mišljenja u slikama, možda je ono opće svojstvo ljudskog uma, ali sigurno nije svojstvo poezije. To je pokazao Šklovski kritizirajući Potebnjinu tezu da je poezija mišljenje u slikama. Dakle, poezija je, pa onda - generaliziramo li - i književnost, nešto što je bitno suprotstavljeno tom svakodnevnom ili izvanknjiževnom iskustvu, u tome je zapravo njena važnost. To je u najužoj vezi s praktičnom primjenom i zato je važno da se ta, kako Èpštejn kaže, izolacija ili, kako s jednako negativnim podtekstom kažu drugi, autonomija, očuva. Samo je iz te pozicije moguće da književnost djeluje u društvu. Zašto? Zato što je u književnosti jezik - koji kao predmet proučavanja dijeli s lingvistikom, a kao sredstvo izražavanja s filozofijom - dan u čistom obliku. Što to znači u čistom obliku ili u laboratorijskim uvjetima? Znači da nema praktičnu primjenu, ali se baš zato može vidjeti kako funkcionira, što se ne može vidjeti tamo gdje ima praktičnu primjenu jer sama praktična primjena onemogućava tu vrstu analize. Giorgio Agamben, da sad dođem do suvremenijih autora, čovjeka definira ne kao bomo sapiens, nego kao bomo sapiens loquendi. Dakle, čovjek je ono biće koje zna (koje je svjesno) da govori. Čovjek, prema Agambenu, za razliku od drugih živih bića koja također imaju jezik, taj svoj jezik mora naučiti, mora ga steći. Postoji razdoblje u kojem ljudsko biće uči jezik i to razdoblje se naziva infancija, djetinjstvo, ali Agambenu je važan latinski korijen infans da bi istaknuo da je tu djetinjstvo shvaćeno kao razdoblje u kojem se ne govori. U takvom poimanju odnosa čovjeka i jezika književnost postaje posebno važna. Agamben tu nikako nije usamljena pojava, čitav niz autora - koji su uglavnom filozofi, što mi se čini kao dobar primjer interdisciplinarnosti, da konačno dođem i do naše teme - književnosti daje posebnu važnost upravo iz navedenih razloga. Adorno, Benjamin, Gadamer, Derrida, Lyotard, Nancy, Agamben, da sad ne nabrajam dalje (mada mogu ako nekoga zanima), dakle čitav niz autora ne proučava književnost kao filozofski predmet premda su po vokaciji filozofi. Drugim riječima, njihova perspektiva nije filozofska iako su oni filozofi. Njihovi tekstovi o književnosti su tekstovi u kojima oni, da tako kažem, odustaju od prerogativa koje filozofija inače ima s obzirom na 
predmete kojima se bavi, baš zato što je književnost, kao i filozofija, nešto što se ostvaruje u jeziku. Derrida će u tom smislu reći kako Valéry podsjeća filozofiju da se filozofija piše. To je ono što filozofija zaboravlja da bi bila filozofija, a književnost joj omogućava da se toga sjeti i da se obogaćena tim iskustvom vrati svom primarnom cilju. To omogućuje da se svakovrsne uobličene predodžbe - uključujući, jasno, kojekakve stereotipe, ali zapravo predodžbe bilo koje vrste - shvate upravo kao ono što jesu - tekstualni tropi - a ne kao stvarno postojeći metafizički entiteti. Kad se tako shvate, oni dovode, kao što znamo, do katastrofalnih posljedica i u tom smislu je svesti ih na tekstualne trope radikalan zahvat.

E sad, što se tiče tih filozofa koji su se bavili književnošću, svi su oni obilato citirani zadnjih pedesetak godina u proučavanju književnosti i na njih se neprestano poziva. Sva ta imena su vam sigurno poznata. Međutim, zanimljiva stvar je da se pritom isključivo poziva na njihove tekstove koji se ne bave književnošću, iako su svi napisali mnogo tekstova o književnosti, neki i čitave knjige. No, ti tekstovi ne da nisu u središtu interesa proučavatelja književnosti kad se pozivaju na rad tih filozofa, nego se oni posve ignoriraju, uopće se ne spominju. To je, meni se čini, itekako simptomatično i u tome 118 vidim krivnju o kojoj sam govorio prošli put. Najplastičnije se to vidi iz jednog primjera koji, doduše, nije iz filozofije, nego antropologije, ali posrijedi je ista stvar. Naime, Clifford Geertz u predgovoru svoje knjige The Interpretation of Cultures izrijekom i nimalo dvosmisleno piše kako je njegova ambicija da na proučavanje kulture primijeni metodologiju koju Auerbach, Frye i Eliot primjenjuju na proučavanje književnih tekstova. Drugim riječima, on je zapravo svoju metodologiju razvio polazeći od onoga što je usvojio iz metodologije proučavanja književnosti. Kad se, međutim, Geertz uvodi u proučavanje književnosti, on se pojavljuje kao netko tko omogućuje nekakav novi obrat, čuveni kulturni obrat, the cultural turn, koji bi imao donijeti nešto sasvim novo. Naravno, to nešto sasvim novo dobije se tako da se iz njegove metodologije odstrani sve ono što je preuzeo iz književnoteorijskog - ili kako god ga nazvali - naslijeđa. Koje on sam smatra svojim polazištem, ako ne i najvažnijim momentom svoje metodologije. Taj se slučaj ponavlja is Lacanom is raznim drugim autorima. Proučavateljima književnosti imalo bi biti vrlo zanimljivo da Lacan, govoreći budućim psihoanalitičarima u Rimu o kurikulumu, o tome što bi trebalo predavati na fakultetu na kojem bi studirali budući psihoanalitičari, kaže da su tu najvažniji predmeti poetika, retorika, lingvistika i sve što se tiče jezika jer, naglašava, ono čime se mi bavimo, naš predmet, nije bolest, naš predmet nije svijest, naš predmet nije pacijent, naš predmet je - govor. Dakle, ako se 
želimo baviti svojim predmetom, kaže Lacan, mi moramo učiti od onih koji su razvili metodu proučavanja jezika, a to je prije svega, kao što je govorio naš učitelj Freud, poetika. Ako to ne učinimo, onda ćemo biti u jedinstvenoj situaciji da sami sebe lišavamo sredstva koje bi nam omogućavalo da dođemo do cilja kojem težimo. To je upravo ono na čemu zadnjih nekoliko desetljeća ustrajno radi proučavanje književnosti: onemogućava samom sebi da dođe do cilja kojem teži.

Svi ti problemi su, dakako, problemi statusa retorike. Razvoj moderne teorije književnosti, modernog proučavanja književnosti, ustvari se vrlo simptomatično podudara s nestankom retorike iz općeg obrazovanja. Dok je god retorika bila osnova i osnovnoškolskog i srednjoškolskog obrazovanja - kao i dok su to bili klasični jezici - glavni problemi književne teorije zadnjih sto pedeset godina nisu bili na dnevnom redu naprosto zato što su to stvari koje su svakome bile očite. Da je književnost umjetnost riječi, to je Šklovski morao objašnjavati tek onda kad to više nije bilo svakome očito. U sedamnaestom, šesnaestom, petnaestom ili bilo kojem ranijem stoljeću, pa i u osamnaestom, to bi bilo besmisleno, to je svakome jasno, to je elementarna stvar za svakoga tko je čitao Kvintilijana. Naravno da njegov Odgoj govornika nije književnokritička niti književnoteorijska rasprava, to je retorička rasprava, koja tek između ostaloga pokriva i književnost jer se bavi raznim oblicima upotrebe govora, ali pritom jasno objašnjava kako je upotreba jezika u književnom tekstu specifična. Kad se Kvintilijan više nije čitao, to je dovelo do situacije u kojoj je Jakobson morao uvesti novi koncept da bi rekao da se proučavanje književnosti bavi onime što je specifično za književno djelo i da se to zove literarnost. On nigdje ne definira što je literarnost niti kako se postiže, što je ključna odlika njegovog pristupa koja je u recepciji toga pojma kasnije potpuno iskrivljena. Važna je i slika koju on s tim u vezi daje, a to je da se proučavanje književnosti ponaša - to je situacija otprije sto godina, a mislim da je lako uočiti da je ona danas potpuno ista, ako ne i gora - dakle proučavatelji književnosti se ponašaju kao policija koja dođe na mjesto zločina i onda pohapsi sve koje tamo zatekne nadajući se da je netko od njih ubojica. $\mathrm{Na}$ isti se način proučavatelji književnosti bave historiografskim, psihološkim, biografskim, sociološkim i raznoraznim drugim aspektima - ovo sad više nije Jakobson - za koje su uglavnom u većoj ili manjoj mjeri nekompetentni. I onda se to zove interdisciplinarnost. Dok upravo tamo gdje bi moglo biti interdisciplinarno, proučavanje književnosti to propušta učiniti. Prava bi interdisciplinarnost - govorim iz pozicije proučavanja književnosti - bilo recimo to što rade oni autori koje sam spomenuo, koji su se doista bavili književnim tekstovima iz 
druge perspektive a da ih nisu podređivali toj perspektivi, dapače, bavili su se i određenjem književnosti. Uostalom, što je književnost i jest filozofsko pitanje, a ne pitanje za proučavatelje književnosti. $U$ tom smislu bih mogao završiti pozivanjem na, uz Agambena i Nancyja, jednog od malobrojnih živih među tim autorima, a to je Jacques Rancière, koji s obzirom na odnos prema književnosti - zapravo, umjetnosti općenito, ali nas sada zanima književnost - razlikuje tri režima: etički, mimetički i estetski, s time da samo estetski režim priznaje autonomiju ili, što bi rekao Èpštejn, izolaciju književnosti. Mimetički, doduše, priznaje da postoji nešto takvo kao književnost, ali samo na razini zanimanja, profesije, to je nešto što je eklatantno društveno integrirano. Etički režim pak uopće ne priznaje specifičnost umjetničkog djela, nego ga naprosto tretira kao i bilo koju drugu društvenu pojavu, isključivo s obzirom na moral. Očigledno je da je etički režim na djelu svaki put kad se neko djelo pozove na red zato što kvari mladež, ili uznemirava javnost, ili što ja znam. Mimetički je režim onaj gdje postoje različita cehovska i slična profesionalna udruženja koja određuju što jest, a što nije književnost, što u slučaju, recimo, socrealizma ili kakve druge službeno preskriptivne poetike izgleda prilično drastično. Zapravo je taj princip potpuno isti i u 120 političkim uređenjima koja nisu tako očito cenzorski raspoložena. Estetski režim, za razliku od ta dva, uopće nema nikakve kriterije, osim što svaki put iznova postavlja pitanje po čemu je neki tekst književnost. To je stav koji zastupaju svi autori o kojima sam govorio, a koji zastupa i velik dio drugih autora na koje se zagovornici raznih vrsta etičkog ili mimetičkog režima u proučavanju književnosti zadnjih pedeset godina pozivaju upravo kako bi - mislim da uopće nije pretjerano tako reći - disciplinirali književnost, bilo etički bilo mimetički, to je sad sasvim svejedno, ali u svakom slučaju kako bi onemogućili estetsku dimenziju kako je tu opisana. $\mathrm{O}$ očuvanju tako shvaćene estetske dimenzije ovisi opstanak humanistike općenito, a možda i neke dalekosežnije stvari. O tome Agamben piše u svojoj knjizi pod naslovom Što je stvarnost? kad opisuje slučaj jednog talijanskog fizičara koji je nestao 1930-ih godina, svojevoljno je nestao i nikad nije razjašnjeno što je bilo s njim, ali o tome eventualno kasnije. U svakom slučaju, poanta knjige je da ako je znanost - konkretno se radi o fizici, Majorana je bio fizičar, vrlo perspektivan Heisenbergov učenik - priznala da se stvarno stanje sistemā nikada ne može spoznati i da se jedino mogu razvijati različiti statistički modeli koji proučavaju vjerojatnost pojave određenih događaja, onda ti sistemi nužno zamjenjuju stvarnost i stoga pitanje što je stvarnost više nema nikakvog smisla. Agamben u tome vidi katastrofalne posljedice, a Majoranin nestanak kao protest protiv te situacije, protest koji svoj vlastiti 
život stavlja kao ulog. Naime, tim je metodama nemoguće ustanoviti što se s njim desilo - naravno, vjerojatno je mrtav jer je nestao još 1938. - ali opet, vjerojatnost nije izvjesnost. Hvala.

Milena Žic Fuchs: Članak na hrvatskom koji će valjda jednog dana izaći napisan je na poziv Hrvatskog filozofskog društva još 2013. godine i nakon toga je nastao prvotni tekst, ali s jednom zanimljivom poviješću ovoga o čemu ću govoriti, a to je kako gledaju na nas, tj. na humanističke znanosti u Europi. U jednom sam trenutku morala povući rad, jer je lijepi broj godina prošao od 2013. godine, a ja sam ga morala nadopuniti s obzirom na sva europska zbivanja ... Oni koji me bolje poznaju znaju da sudjelujem, manje ili više uspješno, u artikuliranju europske znanstvene politike. Osvrnula bih se na par riječi koje sam posebno primijetila tijekom tribine. Pasivnost. Ova kratka diskusija o Zakladi za znanost je eklatantan primjer. Po mome sudu, u Hrvatskoj postoji dosta velika pasivnost, dakle ljudi iz humanističkih znanosti vis-à-vis onih koji nas financiraju. Zaklada za znanost je naša nacionalna zaklada, pa evo... Imala sam žustru raspravu s akademikom Vretenarom kad je lansirao prvi natječaj isključivo na engleskom. Tada sam mu pokušala objasniti da u Europi ne postoji nacionalna zaklada koja prima prijave samo na engleskom. To je u Njemačkoj ili Francuskoj nezamislivo, ustvari bilo gdje je nezamislivo. Uz političke pritiske to su promijenili. Zašto je ovo važan uvod? Jer sad ćemo prijeći na europski kontekst, ali govorim ponajprije o našoj situaciji ovdje. Ono što ja smatram pasivnošću je da se mi premalo javljamo u smislu - ovo je velika riječ - pobune protiv određenih odluka ili okvira financiranja. Javili smo se za hrvatski jezik, to jesmo, i to vrlo žustro, ali da u Zakladi nema mjesta ni za kakvo multi-, inter-, transdisciplinarno istraživanje, to je neprihvatljivo. Time ne mislim da se na bilo koji način moraju ukloniti oni paneli koji se bave određenim područjima i temama, ali da za ovo nema prostora u današnje vrijeme... Ovo što ja zovem preobrazbom europskog istraživačkog prostora i doista se pojavljuju nove paradigme znanja, i to je ono što smo ovdje čuli izraženo na različite načine, osim od kolege Brleka. Dakle, imamo li nove paradigme znanja, to je pitanje? E sad terminološki, bilo mi je vrlo zanimljivo slušati što ste govorili. Ovo što ću sada reći nije uklesano u kamen, jer to što se govorilo o inter-, multi-, transdisciplinarnosti, to je u jednom trenu bilo teško razlučiti. Međutim, danas su se rasprave polako slegle (iako se svi ne drže toga). To naglašavam, jer sada postoji više-manje konsenzus o terminologiji. Kada se govori o inter-, to je unutar područja. Dakle, ako imate književnost, lingvistiku i arheologiju, govorim napamet, to bi bilo interdisciplinarno. 
Kada prelazite granice područja kao što nas dvije očito prelazimo, jer ja idem iz humanističkih znanosti u neuroznanost, kao i kolegica [Blažević], dakle prijelaz na druga područja, odnosno njihovo spajanje bi bilo multi-. Transdisciplinarnost se rabi poglavito za ona istraživanja koja direktno ciljaju na pomoć čovjeku u najširem smislu te riječi. Čovjeku, društvu, ali s naglaskom da je to primarni cilj. To vam je, primjerice, takozvana personalizirana medicina, područje o kojem ja danas neću govoriti, inače vrlo zanimljivo. Kod nas je još uvijek na samim počecima, ali dobro. Mi smo još uvijek u vremenskom određenju famoznog Obzora [2020]. Ja jedva čekam da to prestane jer Obzor je krivo krenuo od samih početaka. On je bio zamišljen kao odgovor tzv. Velikim izazovima. To su klimatske promjene, sve moguće vrste goriva, personalizirana medicina itd. Kad je izašao prvi službeni dokument pod nazivom Green paper, ne mogu vam opisati šok koji sam doživjela. $U$ to sam vrijeme vodila humanističke znanosti Europske unije, tj. predsjedala Stalnim odborom za humanističke znanosti Europske znanstvene zaklade. Nijednom riječju, u vrlo opsežnom dokumentu, nisu se spomenule humanističke ni društvene znanosti. Onda me moj kolega sir Roderick Floud, koji je vodio društvene znanosti, nazvao iz Londona i pitao 122 me: "Čuj, ja slabo vidim, jesam li ja to dobro pročitao da nas nema nigdje?" Rekoh mu: "Jesi, nema nas nigdje." Tada se digla velika halabuka, on, ja i još dvoje kolega iz Njemačke organizirali smo tzv. Otvoreno pismo koje je upućeno tadašnjoj povjerenici koja je de facto bila političar. Jer, pazite, povjerenici mogu biti, kada je znanost u pitanju, ljudi iz znanosti, a mogu biti političari. Máire Geoghegan-Quinn iz Irske bila je pravi političar. Ona nije imala ni sluha ni razumijevanja za bilo kakve discipline naših područja. Naše nadaleko poznato otvoreno pismo prvi je potpisao Neven Budak, ja sam to pomno pratila. Kada sam vidjela Nevenovo ime, odmah sam se rascvala. Iz Hrvatske je pristiglo jako puno potpisa i doista je cijeli pothvat urodio plodom. Jer ako jeste rasni političar, onda Vam je otvoreno pismo koje je na kraju potpisalo preko trideset tisuća znanstvenika i institucija dovoljan poticaj da krenete u promjene. Kako je povjerenica doista bila pravi rasni političar, stvari su se brže-bolje mijenjale i preokrenuo se čak i naziv, tako da smo od Velikih izazova došli do Društvenih. Naime, povjerenica je mislila kako ce tim nazivom Societal Challenges primiriti dio akademske zajednice i da će svi biti sretni. Naravno da se to nije dogodilo. Ali ono što je rečeno do sada na ovom okruglom stolu, na mnogo načina se na europskoj razini raspravljalo o tome. Došlo je do pomaka, ali hoće li se taj pomak održati, ja doista ne znam. U okviru FP9 [novi Okvirni program Europske unije za istraživanje i inovacije za razdoblje nakon 2020] koji je na pomolu, jer sada 
idu zadnji natječaji za Obzor [2020], ima nade da će stvari biti bolje, iako sam vrlo oprezna jer odlazi Carlos Moedas, sadašnji povjerenik. Naime, njemu mandat istječe, a pitanje je koga ćemo dobiti. Valja mu priznati, a to je već prošlo Europski parlament, da se Obzor, koji je bio težak osamdeset milijardi eura, sada penje na sto dvadeset milijardi. Sto dvadeset je izgledno. Postavlja se pitanje tog većeg kolača, kome i kako će što ići. To još nije razjašnjeno i zato mislim da ne smijemo biti pasivni, ni u Europi općenito ni u Hrvatskoj. Sada ću se malo požaliti, imena neću spominjati. Ja sam velika imena i vrsne stručnjake iz humanističkih znanosti - pogotovo dok sam ih vodila za Europsku uniju - ne znam koliko puta molila da se uključe u rad raznih tijela, jer ako te nema na tim sastancima, onda lako nestaneš, i na nacionalnoj razini, ali i na onoj europskoj. Međutim, od naših kolega ponajčešći odgovor je uvijek bio isti: "Nemam vremena." To je, nažalost, naša realnost. Ne znam zašto Hrvati nemaju vremena, ja sam u svega nekoliko navrata uspjela dvoje ljudi uspješno odvesti u te vode. Moram priznati da nije uvijek lako. Mora se putovati, mora se puno raditi, to doista nisu izleti, ali to je priroda tog posla.

Sad idemo na ovo što ću vrlo kratko s nekoliko primjera nastojati pokazati. Pitanja koja su se nekako prožimala kroz ova tri izlaganja tiču se interpretacije i integracije tradicionalno viđenih podataka i rezultata u okvirima širih mreža znanja, kao što je kolegica Blažević vrlo zorno prikazala. Dakle, te mreže znanja su po definiciji kulturno određene i u okviru Obzora 2020. imaju za cilj društvenu primjenjivost. Tako bi trebalo biti. Koliko se uspjelo u tome tek će se vidjeti... Rade se analize, ali već sada znam da to neće biti nešto nama na čast, bih rekla, i u našu korist. Te mreže znanja, odnosno ja ih zovem kulturama znanja jer to nije samo puko spajanje, kao što ste vi [Z. Blažević] već pokazali - to su, dakle, nove kulture znanja koje nastaju suradnjom znanstvenika različitih profila iz različitih područja. Moja ekipa je imala veliku sreću da su nas uzeli pod okrilje Instituta za mozak na Salati i mi radimo, ali ne zahvaljujući Zakladi, nego činjenici da Institut ima Znanstveni centar izvrsnosti. To znači da ima i novaca i valja istaknuti da oni vrlo zdušno sudjeluju u tom pothvatu. Tako da smo našli krov nad glavom i baš smo, mogu reći, izvrsno primljeni i izvrsno surađujemo. [Slijedi dio izlaganja uz prezentaciju.] Što se tiče teorijske razrade, nju je prvi izložio jedan od meni omiljenih filozofa, Nijemac Jürgen Mittelstrass. On je naglasio da se mora shvatiti da postoji empiričko znanje - govorio je o svim znanostima, ne samo humanističkim - i ono koje on naziva orijentacijskim znanjem. Empiričko znanje trebalo bi, po njemu, biti samo podlogom, tj. točka od koje se polazi i kreće prema orijentacijskom znanju koje bi po 
definiciji trebalo biti kulturno određeno i društveno primjenjivo. Dakle, da je to čovjeku, pojedincu i društvu na korist. Mene je jako zanimalo postrani čime se ja osobno bavim - kako funkcioniraju ti multidisciplinarni projekti, pogotovo oni koji s vremenom postaju i transdisciplinarni jer doista žele pomoći čovjeku. Pukim slučajem na jednoj konferenciji upoznala sam ravnateljicu Švicarskog saveznog instituta za vodnu znanost i tehnologiju. Dakle, Svicarska nema mora, ali ima institut toga naziva. Institut je po širini istraživanja kojima se bavi doista impresivan. Ravnateljica me pozvala na suradnju jer se našla u problemu kojeg nije mogla riješiti znanstvenim potencijalima u samom institutu. Tako je došlo do suradnje poglavito prirodoznanstvenika te onih iz humanističkih znanosti. Dogodio se prevrat. Naime, mene je sablaznio podatak da je u vrijeme prije nego što se počela primjenjivati SODIS-metoda u Africi i Aziji dnevno od dijareje umiralo od osam do deset tisuća djece. Ne govorim o odraslima. To je doista strašno i velik je problem. Znanstvenici u tom institutu krenuli su razmišljati kako riješiti ovaj gorući problem. Izumili su posebne plastične boce u kojima, ako ih ostavite na suncu šest sati, ugibaju sve bakterije. Metoda je primijenjena najprije u Africi, a potom se polako širila i u Aziji. Danas SODIS

124 rabi više od pet milijuna ljudi u otprilike trideset zemalja u razvoju. Oni su postigli nevjerojatne rezultate u smislu smanjivanja smrtnosti djece, dapače, u nekim zemljama toga skoro više i nema da djeca umiru od najobičnijih bakterija. Počeli su sa socio-psihološkim studijama i analizirali različite strategije kako učinkovito i uspješno podučavati korisnike. Međutim, što se dogodilo? Unatoč svim tim naporima njihovi uspjesi bili su raznoliki u različitim zemljama. Imali su i sociologe i psihologe itd., ali nešto je nedostajalo. Kako sam rekla, ravnateljica navedenog instituta pitala se zašto ta vrlo jednostavna, ja bih rekla gotovo primitivna metoda, za pročišćavanje vode negdje prolazi, a negdje ne? Pozvali su mene, a ja sam pozvala svoju ekipu iz Stalnog odbora za humanističke znanosti, dakle znanstvenike iz različitih humanističkih disciplina. Rješenje se iskristaliziralo vrlo brzo. Kada su se radili inicijalni koraci prema trideset zemalja u Africi i Aziji, nitko nije analizirao kulturološke, religijske odrednice. Te simboličke, vizualne vrijednosti morale su se početi uzimati u obzir pri primjeni SODIS-metode. Upravo ovakvim sveobuhvatnim pristupom rezultati su se bitno poboljšali.

Jedna od stvari koje su sad veliki hit u neuroznanosti i lingvistici, ali i daleko šire jesu takozvani robotići. Evo, vidite, ovaj robot [na slici] se zove René i riječ je o robotima koji su nazvani po nama dobro znanim likovima iz serije 'Allo! 'Allo!. Dakle, imate Herr Flicka, Helgu, Renéa i sve ostale. René je bio prvi koji je stigao u Zagreb. Čemu služe ti robotići? Naime, 
oni su vrlo bitni kod dijagnosticiranja autizma, pa čak i iznalaženja načina kako pomoći djeci koja imaju autizam. Zašto robotići? Autistična djeca teže ili nikako ne komuniciraju s ljudima. A ti robotići su kao koala-medvjedići, kada ih primite, oni vas zagrle jer su tako napravljeni. Ekipa se formirala: spojili su se kolege s FER-a, s Edukacijsko-rehabilitacijskog fakulteta, i to sve u suradnji s Hrvatskim institutom za istraživanje mozga. Ustanovilo se da René i ostali robotići moraju naučiti hrvatski, inače su za hrvatsku djecu neprimjenjivi, moraju naučiti „kulturu“, iz književnosti moraju poznavati barem ono što je relevantno za djecu... I odjedanput je potreba za humanističkim znanostima u ovoj hipermultidisciplinarnoj priči narasla do nevjerojatnih razina, do razina da smo izašli u mjesečniku Horizon koji izdaje Europska komisija. Baš se nas spominje tamo, dakle naše Sveučilište. Meni je bilo izrazito drago da se i nešto naše napokon promoviralo jer toga ionako nema previše.

Ja sam 2012. organizirala prvo interdisciplinarno okupljanje mladih ljudi u Italiji, u Alpama, gdje smo ih izolirali od cijeloga svijeta, jer do Milana i prvih diskača je barem dva i pol sata vožnje. Tako da smo ih zbilja izolirali. To su bili mladi ljudi, vrlo skeptični prema bilo kakvom interdisciplinarnom "nečemu". Prvu večer kad su stigli, vidim da književnici sjede na jednom mjestu, ekonomisti na drugom, inženjeri na trećem. Onda smo promijenili strategiju i stavljali imena na stolove tako da su morali razgovarati s ljudima iz drugih struka. Što je rezultiralo iz te suradnje može se vidjeti u časopisu European Review gdje se govori o jednoj konferenciji koju sam organizirala u Stockholmu 2017. Budući da sam bila glavni organizator i urednik, na prvom mjestu je bio članak jedne od sudionica skupa u Italiji, Helen Bridle. Ona je inženjerka i biolog i u svom radu pokazala je na temelju analize da su sudionici na skup došli s velikom skepsom. Međutim, jedan dio njih vrlo brzo se uključio u razne projekte povezane s vodom, osnovali su i svoj časopis, te se suradnja održava i danas. Ja sam bila u poziciji da sam takav skup mogla organizirati jer sam imala novčana sredstva. $\mathrm{Ne}$ mogu zamisliti tko bi u Hrvatskoj dao novac za takvo što, ali dobro. Sad se počelo sve pripremati za novi FP9 koji će se, uzgred rečeno, zvati Horizon Europe. I prvi put je Europska komisija, ali doista po prvi put, prije izrade samog programa izabrala dvanaestero ljudi, e za koje su smatrali da mogu doprinijeti budućnosti znanosti u Europi. Ponavljam, to se dogodilo prvi put, naime prije bi Komisija sjela, odnosno njeni činovnici bi se sjeli i krenula bi izradba novog FP-programa. Kao što već znamo to nije uvijek baš funkcioniralo na zadovoljstvo cjelokupne akademske zajednice. Moja malenkost bila je članicom te skupine i ovo nije samohvala jer sad cete 
vidjeti učinak i zašto je pasivnost nešto što ja ne priznajem. Riječ je bila o opsežnom i iscrpljujućem poslu. Ja sam posvetila gotovo godinu dana svog života izradi ove male knjižice. Radili su je ljudi iz industrije, znanstvenici, inovatori... Vrlo šarena skupina od dvanaestero stručnjaka proizvela je tih 11 točaka koje određuju budući FP-program, a to znači sedam godina, i to s uvećanim sredstvima. Što je bila moja misija? Ovdje neću ulaziti u to što su "misije" (tehnički termin iz izvješća Lamyjeve skupine). Prvo što piše jest da će svi ti veliki projekti, a to su te "misije", po definiciji uključivati, štoviše integrirati, društvene i humanističke znanosti. Dakle, ne može se više bez nas. Bila sam jedini stručnjak iz humanističkih znanosti u Lamyjevoj skupini. Zbog toga dolazimo do ovog drugog istaknutog dijela [u prezentaciji] gdje piše: "SSH researchers will initiate and lead them". Drugim riječima, postignuta je ravnoteža. Da budem iskrena, to vam je moja vizija kako bi znanost trebala biti financirana, odnosno kako joj treba davati poticaj jer bez novaca nema ni sveobuhvatnih istraživanja. Dakle, mora postojati ravnoteža.. Ako netko hoće raditi Shakespearea, neka ga radi. To je samo prinos svemu ovome o čemu sam govorila, dakle kulturi, čovjeku, duši, ako smijem reći to u ruskom smislu. [smijeh] Bilo kakva isključivost, bilo na jednu bilo na 126 drugu stranu, nije zdrava, nije dobra. Za mene je veliko pitanje: kako postići ovakvo poimanje znanosti s izraženom društvenom ulogom? Ja vjerujem da mi služimo nekome. Netko tko analizira Shakespearea, pa naravno da će to onda ići dalje... oprostite što uzimam anglističke primjere... da će ići dalje s naglaskom na čovjeku i njegovom kulturnom okruženju. I to je po meni, osim ove ravnoteže u financiranju, najveći izazov europskog istraživačkog prostora. Naime, gdje kreću problemi? Izvješće Lamyjeve skupine objavljeno je u srpnju 2017. i sad cijelu stvar preuzimaju naša ministarstva, čitajte MZO. Oni sad za nastavak izrade ovog FP-programa šalju svoje ljude. Ne znanstvenike, nego svoje činovnike. Oni propagiraju isključivo STEM, što vas neće iznenaditi, i to znam sa službenih sastanaka. To što govore o humanističkim znanostima neću ni citirati, možda kada napišem još jedan članak. Mi bismo - ja bih to nazvala humanističkom zajednicom - budno trebali pratiti što se tamo zbiva. U novinama kod nas nema informacija o tome. Naime, ono što ja dobivam preko maila, to je privatna korespondencija. Mi nismo ni informirani, a FP9 je već na putu. Moja slavna slika [u prezentaciji] s kojom volim zahvaliti publici jest slika alpinista, kako ih moja Marina [Grubišić] zove „slavni penjači“. Gledajte, put je točno ovakav kakav je predočen na ovoj slici. Ono što ja znam jest da kad se dođe na vrh, put je mukotrpan i iscrpljujući, ali pogled kada uspiješ vratiti humanističke znanosti gdje im je pravo mjesto... pogled je božanstven. Hvala vam lijepa. 
Davor Dukić: Evo, za sve naše uvodničare, sve četvero, skoro pa dva sata, s time da smo danas imali nešto manje uvodnih izlagača, ako se ne varam, ali bilo je zanimljivo, bilo je živahno. Priznao sam svima da sam se malo bojao da će izlaganja, doduše, biti zanimljiva, ali da će se možda promašivati. Oni su se potrudili da tako ne bude, mislim da je bilo dodira i prožimanja i više nego što su i sami očekivali. Oduzet ćemo riječ na neko vrijeme našim gostima, a pozivam vas ostale da se javite za raspravu.

Zvonko Kovač: Evo ja sam pozvan kao diskutant pa se javljam, iako sam se mislio suzdržati od diskusije jer sam došao ovamo misleći da se radi o elitnim znanstvenicima kojima se nikada ne odbijaju projekti, no sada sam saznao da se takve stvari događaju i njima, ne samo južnoslavistima. Govorilo se o "teškom" prekoračivanju lingvistike u znanost o književnosti, a da ne govorimo kako to izgleda na širem interdisciplinarnom području, naime mislim da na Fakultetu pomalo gubimo pravu terminologiju. $\mathrm{U}$ jednom času smo umjesto o dvopredmetnosti, jednopredmetnosti - iako je to zadovoljavalo studijski okvir naše interdisciplinarnosti - počeli govoriti o interdisciplinarnosti, što nije sasvim točno. Govorim samokritički jer sam nedavno objavio predavanje o slavistici i interdisciplinarnoj solidarnosti (sada i u internetskom izdanju: https://openbooks.ffzg.unizg.hr/index.php/ FFpress/catalog/view/23/30/1093-1)

Razumjeli smo što mislimo s tim konceptom dvopredmetnosti naših studija, a sad je sve nekako postalo interdisciplinarno iako, kao što je Tomislav rekao, kada smo na području slavistike, u Miklošičevo i Jagićevo doba ona je zapravo bila jedna disciplina, a to je bila slavenska filologija. Ali se vrlo brzo, još u doba djelovanja Matije Murka u Pragu, počela dijeliti na manje jedinice, konkretno na južnoslavensku filologiju, a postupno i na ono što danas zovemo slavistička znanost o književnosti i jezikoslovna slavistika. Kasnije je ta podjela išla onako kako je kolega Brlek i najavio, po tim nacionalnim filologijama, posebno kod nas i u slavenskim zemljama, i danas smo zapravo u situaciji da slavistike u tradicionalnom smislu kao discipline, pa i šireg predmetnog područja više nema. Dakle, tu se sad više uopće ne radi o disciplinama, nego postoji predmetno područje s dvije-tri discipline (ako dodamo neko arealno-kulturološko interdisciplinarno područje, s težištima na pojedine zemlje i jezična područja ili ako pridodamo slavistiku studijima povijesti istočne Europe ili komparativne književnosti i sl.). Naravno da je to dovelo do krize slavističkih studija, pa se dogodilo da je prilikom sastavljanja nove koalicijske vlade u Njemačkoj dogovoreno da se ti tržišno manje uspješni studiji posebno financiraju i to je dalo rezultate, tako da su 
se slavistički studiji, koji su bili također među tim ugroženima, počeli dizati, kadrovski, projektno i na sve druge načine. E sad, mislim da bismo kod nas i za novu reformu studija trebali razjasniti pojmove dvopredmetnosti, odnosno interdisciplinarnosti. Koliko je na području znanosti o književnosti interdisciplinarnosti među pojedinim studijima književnosti? Jesu li to discipline ili su samo neka uska specijalistička predmetna područja? Često nose imena katedara, Katedra za englesku i američku književnost, Katedra za slovenski jezik i književnost itd. Jesu li to discipline ili samo specijalizacije? Ono gdje bi bile discipline, gdje prekoračujemo ono što imamo s onom crticom u "društveno-humanističke", to je zapravo kod nas sustavno onemogućeno, i to začudo s "bolonjom", jer su se kod nas silno razvili tzv. jednopredmetni studiji koje smo nespretno počeli zvati jedno- ili monodisciplinarni. A ti su jednopredmetni studiji orijentirali stručnjake prema užem, jednom cilju, ili prema ishodima učenja, prema kompetencijama koje će biti koncentrirane samo na jednu i sve užu specijalizaciju. Na bohemistiku s jedne, danas je bilo spomenuto, te na slovakistiku s druge strane, čije zajedničko studiranje ipak omogućava dvopredmetni studij, premda on još uvijek ne obavezuje znanstvenike npr. na šire zapadnoslavenske studije. S druge strane, mi se 128 danas ne možemo interdisciplinarno postaviti u svom radu sa studentima jer nam je jednopredmetnost onemogućila da na studiju imamo povjesničare, na početku su i kroatisti bili jednopredmetni, psihologe, sociologe, sve te znanosti koje su vrlo važne za bilo kakav interdisciplinarni pristup književnosti. Naprosto nemaš s kime razgovarati jer u svom vlastitom svakodnevnom radu imaš koncentriranost ne samo na jednu disciplinu, kao što je povijest književnosti, nego na jedno usko shvaćeno predmetno područje, na jednu specijalizaciju, pa i subspecijalizaciju. I mislim da je to ogroman problem onoga što se zove interdisciplinarnost u širem smislu. Ono što se proizvodi kao rezultat takvog stanja, čini mi se, iluzija je mnogih stručnjaka, mnogih znanstvenika kod nas, koji misle da ako se takva specijalizacija dobro osmisli s ishodima učenja, sa što užim kompetencijama, da smo onda dublje u toj znanosti, odnosno u nekom predmetnom području. A ja upravo mislim da je obratno, da ako nemamo tu usku specijalizaciju, nego smo otvoreni prema međupredmetnom povezivanju, prema srodnim disciplinama, pa i prema udaljenijima, da smo bliže znanosti unutar koje tu specijalizaciju prakticiramo. Na sretnijim sveučilištima, u manjim gradovima ili kampusima studenti (pa s njima i nastavnici) mogu interdisciplinarnost trenirati takoreći svakodnevno jer možeš studirati matematiku i književnost, i gotovo sve moguće kombinacije. Gdje mi možemo proizvesti takvog čovjeka? Nigdje. Mi naprosto nemamo materijalne preduvjete da razvijamo otvorenost 
znanosti i interdisciplinarnost. S druge strane, na samom Fakultetu smo propustili priliku i sada da se vratimo na "koncept dvopredmetnosti", na veću međusobnu povezanost naših studija. I danas sam isto postavio pitanje hoće li Fakultet imati snage da nekom odsjeku kaže: molim, nemojte razvijati jednopredmetne studije, nego dvopredmetne. Odgovor je bio da neće, dakle da uprava nema snage jednom odsjeku narediti da krene u, ajde da kažemo, interdisciplinarne studije.

Davor Dukić: Hvala. Želi li tko od naših uvodničara prokomentirati?

Milena Žic Fuchs: Pa, bih ja. Ja se u potpunosti slažem. Baš gledam, na zapadnoeuropskim sveučilištima rade ovo što si ti napomenuo. Evo konkretnih primjera: Leuven, Belgija; Karolinska, Stockholm; Leiden, Nizozemska - oni od početka, dakle od prve godine nude opći predmet o društveno-humanističkim znanostima koji je predložen na našem Fakultetu na prve tri godine. Za to trebate imati vrhunskog iskusnog stručnjaka koji ce to predavati. Ne šalim se, samo kad sam vidjela imena i područja, pa za to moraš biti renesansni čovjek. Ali, što rade ti fakulteti u drugim državama? Oni na mala vrata otvaraju mogućnosti, ali po nahođenju studenata, ne rektora i ne znam koga, da slušaju kolegije is drugih područja, ali paralelno s užom strukom. Zasad se čini da je to relativno nova praksa te da je dosta učinkovita. Meni je uvijek malo smetalo na ovom Fakultetu da smo jako zatvoreni u svoje kućice, bez obzira na to kakve bile. Sjećam se kada sam bila brucoš, što je bilo prije puno godina, išla sam na indologiju slušati sanskrt jer me to zanimalo. Profesorica je vidjela da sam ja neko čudno biće i da nisam na popisu. I prva stvar koju mi je rekla je da ne mogu prisustvovati nastavi. Odgovorila sam joj da mene samo zanima sanskrt, ne želim polagati ispit niti upisivati u indeks, ali da nešto želim naučiti. Odgovor je bio: "Van!" Ja bih htjela da mi otvorimo vrata... kako bi studentima prirodno nadošla ta interdisciplinarna mogućnost studiranja i oblikovanja istraživačkih pitanja, jer nitko se ne rodi interdisciplinaran niti samo da radi teoriju književnosti.

Ivana Peruško Vindakijević: Da, na temu fleksibilnosti... ni sama ne znam koliko sam fleksibilna zato što imamo problem jezične prirode. Mene zanima, recimo, što će tim studentima pisati... O. k., više nema indeksa... Ali u nekom dokumentu će ipak pisati što su završili. Ako mi proizvodimo rusiste, potrebno je predavati i znati ruski jezik da se uopće može pristupiti nastavi. Kako da studenti koji nisu rusisti sudjeluju u takvoj nastavi? Do koje mjere da mi onda tu budemo fleksibilni? $\mathrm{Na}$ temu dijaloga mogu postaviti 
protupitanje: kako da otvorimo drugima vrata ako je naša zadaća da proizvedemo ljude koji će ruskim jezikom vladati izvrsno, dobro ili dovoljno i koji će znati nešto o ruskoj kulturi i ruskoj književnosti? Dakle, kako da nefilološki studiji sudjeluju u spomenutom dijalogu? Ne znam kako to naprosto riješiti s jezikom.

Tomislav Brlek: Jednostavno da bude uvjet. Moraju znati na nekoj razini. Ne moraju znati savršeno, ali moraju znati na razini da mogu pratiti nastavu.

Ivana Peruško Vindakijević: Ne znam je li posrijedi koledžizacija i amerikanizacija studija ili bolja, suptilno razrađena ideja. Na primjeru slavistikâ diljem svijeta - u Njemačkoj, recimo - očigledna je tendencija pada. Kako to dokinuti, što na tom području napraviti, stvarno ne znam. Još jedna stvar oko izolacije i autonomije. To nisu isti termini, Èpštejn to ni na koji način nije...

Tomislav Brlek: Ne, ne, znam da nisu...

Ivana Peruško Vindakijević: Ne mislim da je posrijedi poimanje izolacije kakvo ste vi spomenuli, imajući u vidu novce, projekte, programe i slično. Ja sam Èpštejna namjerno izabrala, naravno, provokacije radi, ali on završava s nečim s čime ste i vi završili. Mislim da on ne zagovara ukidanje autonomije i postojanje puškinologa, dostojevskologa itd., nego samo tvrdi da bi trebala postojati još jedna eksperimentalnija grana uz ove klasične. Možda to možemo promijeniti na razini te nekakve interdisciplinarnosti, što prof. Kovač tvrdi, no što je interdisciplinarnost? Mi potpisujemo na diplomskim radovima da su interdisciplinarni, a riječ je o talijanističko-rusističkim književnim temama, recimo... Je li to interdisciplinarnost? Nije, naravno da nije.

Davor Dukić: Imamo li još komentara, pitanja? Ako smijem malo komentirati naše uvodničare, ajde da krenem od Ivane. Kod vas nije bilo nezadovoljstva u izlaganju, vi ste izložili primjer koji vam je provokativan i primjer svoje prakse kojom ste donekle zadovoljni. Po tom ste se razlikovali od drugih. Onda u sredini [Blažević i M. Žic Fuchs] je bilo stanovitog nezadovoljstva, i to nezadovoljstva institucijama koje nas financiraju, koje vode znanstvenu politiku, i tu smo dobili primjere i argumentaciju odakle to nezadovoljstvo. Nezadovoljstva je bilo i kod Tomislava. Ali ono je ostalo na 
onom tragu na kojemu je on započeo diskusiju na prošlom okruglom stolu, dakle krivica nije nigdje vani, nego kod samih subjekata književne znanosti. S time da onda dolazimo do proturječja: to što Èpštejn vidi kao dominantu, za Tomislava je manjinska praksa. Nema ovdje nikoga da brani zakon, pa ću probati ja. Zakon s malim z, dakle one institucije koje nemaju sluha za interdisciplinarnost. Trebamo li mi od institucija koje vode znanstvenu politiku očekivati avangardnost ili su one na neki način odraz stanja stvari? Treba li naše nezadovoljstvo, drugim riječima, biti upućeno prema Zakladi ili prema drugim kolegama, tj. prema vlastitoj zajednici koja je nedovoljno avangardna, koja je pasivna, inertna ili konzervativna u svom pristupu? To je moje pitanje.

Milena Žic Fuchs: Ja sam ti i jedno i drugo rekla. Dakle, i Zaklada kao institucija, o tome nećemo dalje, ali isto tako pasivnost je riječ koju sam istakla. Ja mislim da smo svi prepasivni, bez obzira na to je li riječ o ovim reformama studija, načinu financiranja, što financirati... Mene boli - koliko ova Vlada već vlada, dvije godine, zar ne? - da mi još uvijek nemamo razrađenu državnu strategiju za znanost. Nemojte misliti da sam ja neki birokrat, ali bi pomoglo kada bi oni napisali a), b), c), kako to već rade, jer mi bismo u tom slučaju mogli naći svoje mjesto pod suncem. Štoviše, mogli bismo raspravom doprinijeti isticanju mogućih prioriteta. Gledajte, mi nismo nikakva iznimka. Prošli je tjedan u Zagrebu bio moj dobar prijatelj i kolega iz Kine, profesor komparativne književnosti Ning Wan, održao je dva predavanja itd. On i ja smo kroz Academiu Europaeu imali akcije diljem Europe da se ovo ukidanje malih jezika i tzv. malih struka zaustavi. Sjećam se kad je egiptologija u Francuskoj skoro nestala s geografske karte. Dogodila se pobuna u Francuskoj. Is tom jednom bučnom reakcijom visokih institucija konačno su ih ostavili na miru. Zasad. Drugo, ja sam alergična na akronim STEM jer je to fikcija. Danas to više ne funkcionira čak ni kod prirodnjaka i medicinara, a u hrvatskom tisku, koliko ga ja pratim, stalno je STEM, STEM, STEM. A ovo sve drugo kao da ne postoji.

Zrinka Blažević: Ja bih se samo nadovezala na Davorovo pitanje. Dakle, ono što je, pretpostavljam, i vaš, ali i moj izvor nezadovoljstva, pa onda i poticaj za ironijski žalac usmjeren prema našim institucijama koje bi trebale financirati znanost, jest da se i u ovom slučaju, kao i u slučaju naše domaće, hrvatske legislative, proklamiraju načela izvrsnosti, da nas se pokušava staviti u rang kompetitivnih, europskih, razvijenih itd. zemalja, da bi se onda... Ta načela stoje u svim izuzetno pompozno sročenim call for papers, odnosno pozivima na prijavu projekata da bi se zapravo u samome procesu 
evaluacije u potpunosti zanemarila, da ne kažem anulirala. To mi smeta. Da su pozivi na prijavu projekata bili drugačije artikulirani, onda bi se čovjek držao neke svoje uske disciplinarne matrice i ne bi pokušavao biti avangardan. Ali čovjek se naivno ponada da se, eto, otvaraju neki prostori i onda se suoči s brutalnom realnošću. To je jedna stvar. Druga je stvar vezana za STEM, ako se mogu nadovezati na vašu diskusiju. Dakle, danas se čak i kod praktičara prirodnih i tehničkih znanosti sve više govori o postempirijskom obratu. Znam da Tomislav ne voli obrate, ali taj obrat je dosta bitan. I oni su zaključili da bez hermeneutike, bez hermeneutičkih objašnjenja njihove zakonitosti ne znače puno. Oni se zapravo okreću interpretaciji i počinju shvaćati da su im društveno-humanističke znanosti bitne upravo da bi sami, unutar svojih znanosti, polučili neke kognitivne ili objasnidbene rezultate.

Zvonko Kovač: Kada bismo, recimo, sada ove svoje razne struke definirali kao discipline... Meni je jako interesantna sintagma kolegice Žic Fuchs "kultura znanja". Svaka od naših disciplina i predmeta, predmetnog područja, ima neku "kulturu znanja". I što je zapravo onda interdisciplinarni studij? Upravo razmjena kulture znanja. A to su onda, znači, tek svojevrsni inter132 kulturni studiji, koje ustrajno, neuspješno zagovaram na južnoslavističkom području... Improviziram sada, studij kao razmjena "kultura znanja". Što bi, dakle, bila "kultura znanja"? "Kultura znanja" bi bila "disciplina" ili "skup znanja" kojima mi proučavamo jednu kulturu, određenu kulturnu situaciju ili čak samo kulturu jednoga razdoblja, ali i međujezične ili međuknjiževne odnose, međukulturnu književnost; pri čemu je onda naše znanje kompleksnije, a time i bliže disciplini ili znanosti unutar koje u osnovi djelujemo.

Milena Žic Fuchs: Onda može biti i proizvod isto.

Zvonko Kovač: Može biti i proizvod, naravno, ali tu se često previše razgraničavamo unutar širega predmetnoga područja, odnosno područja koje proučavamo. Ili, recimo, s obzirom na Zrinkino izlaganje, u suvremenoj književnosti imamo interesantnu historiografsku fikciju. Pisci sada vole pisati kao povjesničari, o sebi, svojim obiteljima, pišu o ratovima, pišu kao povjesničari, ali pripovijedaju bolje od njih. Pisali su tako i prije, to smo zvali povijesni roman, sad to zovemo nekako drugačije. Je li "kultura znanja" povjesničara u nekoj prednosti kod analize takvih tekstova? Evo, to je jedno interdisciplinarno pitanje. Mi se sada možemo kao povjesničari, kao znanstvenici za književnost baviti time, a možemo se baviti tako da posudimo neka znanja od povjesničara, odnosno historiografa. No, u ime "bolonje" 
nemamo povjesničara već skoro dvadeset godina u seminaru, a imali smo ih prije, kada je dvopredmetnost kod nas bolje funkcionirala. Danas ne možete u seminaru reći hajde, kolega, što vi sad mislite, objasnite malo povijesni kontekst s obzirom na ideološku situaciju u prikazu nekog lika itd.

Zrinka Blažević: Odgovor na prvi dio pitanja koji se tiče historiografske fikcije. Dakle, tu povjesničar ne može odveć pomoći književnome povjesničaru zato što je povjesničar, još od Haydena Whitea naovamo, posudio modele analize koja jest zapravo tekstualna, lingvistička, retorička itd. od književnih povjesničara da bi mogao čitati historiografski tekst kao tekst. Povjesničar može pomoći za kontekstualizaciju, za sve one, nazovimo ih tako, ekstrinzične crte nekog književnog djela koje se tiču obilježja produkcije, recepcije, diseminacije, pa čak i recimo transtekstualne cirkulacije tropa ili intermedijalne cirkulacije tropa. Tu bi povjesničar svakako mogao pomoći književnome povjesničaru. Ali kada je riječ o samome žanru, mislim da je na djelu ona cirkularnost o kojoj je govorio Tomislav, a to je da su se zahvaljujući lingvističkom obratu - koji povjesničari ne vole jer se još uvijek boje da će im ugroziti temelje discipline koja u biti jest pri-povijest - suočili s činjenicom da u bazi historijske znanosti jest pripovijedanje i da pripovijedanje nema isključivo izvještajnu funkciju, nego i spoznajnu funkciju u historijskoj znanosti - makar će vam malo koji povjesničar izreći tako heretičnu rečenicu - dakle, upravo zbog lingvističkog obrata jedan dio historičara $\mathrm{i}$ historijska znanost u cjelini jesu osvijestili važnost pripovijedanja, pripovjednosti, retoričkih i poetičkih modela i postupaka itd., i u konačnici proizvođenje referencijalne iluzije, čime se historijska znanost možda čak i približava historiografskoj fikciji.

Zvonko Kovač: To znači da je povijest još samo pomoćna znanost.

Tomislav Brlek: Ne, ne, mislim da je sve to točno, ali, na primjer, jednom Gibbonu ništa od toga ne bi bilo strano.

Zrinka Blažević: Njemu se to podrazumijevalo jer je historijska znanost izašla iz okrilja književnosti tek sa svojim disciplinarnim etabliranjem, a to se zbivalo tijekom druge polovice 19. stoljeća. Do tada je bilo neupitno da je povijest grana književnosti.

Tomislav Brlek: Ja mislim i dalje, njegovim učenicima, pa i lošim nasljednicima. Da se osvijetli problem o kojem je riječ, može se možda pose- 
gnuti za analogijom s ilirskim preporodom. Ljudi koji su u tome sudjelovali bili su svjesni, kao i njihovi pandani u Italiji, da stvaraju naciju. Retrospektivno, međutim, oni postaju otkrivači nečega što već postoji prije njih. Nitko od njih nije imao tu iluziju. Oni su svi do jednoga svjesni: $m i$ ćemo sada stvoriti nešto čega nema, mi ćemo to proglasiti, naći ćemo onda kulturno naslijeđe - Davor zna sve o tome - i stvorit ćemo tu kulturu, taj imaginarij. Svojedobno sam prevodio na engleski tekst kolegice Blažević o Vitezoviću. Ako se dobro sjećam, on opisuje, reklo bi se, objektivne činjenice kao što je administrativna podjela Hrvatske, ali to opisuje potpuno različito ovisno o tome kome piše. Dakle, on prilagodava svoj opis objektivne stvarnosti, administrativna podjela ne bi trebala biti sporna, to nije stvar interpretacije. Naravno, ne piše on o tome da bi toga kome piše izvijestio kakva je administrativna situacija, nego kako bi od njega nešto dobio. A da bi od njega nešto dobio, mora mu prikazati situaciju na određeni način, i tako dalje, i tome slično.

Luka Perušić: Evo, probat ću biti kratak. Cijela ova priča oko interdisciplinarnosti i problema sa suvremenom znanosti dio je mog doktorskog rada i u tom se smislu mučim s njom. Onaj detalj koji ovdje mene brine, čini mi 134 se da bi možda trebalo napraviti razliku između interdisciplinarnosti vani i problema pasivnosti vani i interdisciplinarnosti ovdje i problema pasivnosti ovdje. Meni se čini, dok ovako slušam, da postoji neki generalni problem pasivnosti kod humanista, ali promatrajući kako humanisti vani funkcioniraju, bar izvan srednjoeuropskog Balkana, ja nemam osjećaj da su ti ljudi pasivni. Dapače, imam osjećaj da oni, koliko god mogu, na najbolji način pokušavaju integrirati nekakve svoje tradicionalne znanstvene vrijednosti s onime što se u sustavu događa. Čitao sam o problemima koje imaju, recimo, interdisciplinarci u Australiji, Britaniji, Americi, dakle nekakve tri točke gdje je dosta veliko obrtanje novca, i oni se susreću sa sličnim problemima koje ste vi ovdje navodili, a to je da dobivaju komisije koje ne razumiju kako će se zapravo taj projekt provesti, kojima nije jasno na koji način će funkcionirati metodologija između različitih znanosti i kojima onda nije jasno koji su konkretni ciljevi toga, jer ne razumiju metodologiju, tj. nemaju osjećaja za to što bi to interdisciplinarno po rezultatima trebalo davati. Taj je problem prisutan čak i u poluprivatnoj industriji. Različite europske komisije nemaju razumijevanja za nove, recimo, performativne medije ili nove oblike digitalnih proizvoda, kreativnih proizvoda jer ne razumiju... Jedan klasičan muzičar, muzikolog, ne razumije što se to događa u novim kompleksnim medijima. Medutim, kada oni o tome govore i kada promatram kako njihovi sustavi funkcioniraju - ovdje je navedeno nekoliko fakulteta koji pokušavaju stvoriti 
interdisciplinarnu platformu - zapravo nisam stekao dojam da kod njih vlada neka vrsta pasivnosti. Stekao sam dojam da je, naravno, u jednoj mjeri prisutan, ali mi se čini da je kod nas, dakle u Republici Hrvatskoj to specifičan tip pasivnosti, gdje si ti svjestan da ćeš umrijeti za deset godina i ne angažiraš se. Ono što mene muči je što se onda u tom psihološkom sklopu kod nas događa. Čak i da vani postoji nekakva slična paradigma, mene odmah interesira što se onda tu događa, koji su razlozi, ako hoćemo povijesni ili psihološki, psihički u tom smislu ili kulturološki, nemam pojma, koji su razlozi za to da nemamo vremena i da su svi oko nas idioti? Ima li to veze s preopterećenjem naše zajednice, pa previše radimo? Ima li to veze $s$, ne znam, negativnom selekcijom pri zapošljavanju? Ima li to veze s problemom koji smo imali prije dvadeset pet godina, koji je razorio jedan dio priče koja je funkcionirala? Mene, recimo, te stvari interesiraju. Ja bih volio od vas kao puno iskusnijih istraživača, u kojem god obliku hoćete... Mene bi zanimalo, kada razmišljate o tome koji su to momenti zbog kojih postoji pasivnost u humanistici kod nas, koji su to naši specifični momenti, kako se to prevlada? Jer ovaj komentar "nema se vremena", to je nešto što mene osobno izluđuje. A druga stvar koja mi nije jasna je argument: "On ti je idiot." To su dva elementa, konflikti koje mi svi imamo i koje ja slušam otkad sam dio akademske zajednice. To je jedan problem preko kojega kao da nismo u stanju prijeći, kao da kod nas i dalje vrijedi krvna osveta. E sada, ono što sam primijetio jest da vrlo velik broj članova zajednice doista nema dovoljno psihičke energije da uz sve još mora investirati u ono što nama fundamentalno treba, a to je politička volja. Mene zanima iz perspektive izlagača, ako govorimo o našem stanju, stanju ovdje sada u Republici Hrvatskoj, zašto kod nas vlada pasivnost? Pasivnost je utvrđena, to je definitivno, ja se s time slažem u potpunosti, izluđuje me ta pasivnost, ali me zanima kako vi to vidite, koji su razlozi za tu pasivnost? Osim što nemamo vremena.

Milena Žic Fuchs: Ja imam dvostruki odgovor na to pitanje. Možda sam u krivu s prvim dijelom, ali naša kultura, za razliku od, recimo, angloameričke, u kojoj sam ja rasla i živjela većinu života, ljude ne uči da moraju biti aktivni. Vi ako ste student na američkom sveučilištu, ne možete samo studirati književnost ili medicinu, vi morate biti angažirani. Svaka aktivnost se, pod navodnicima, honorira. To je jedan dio. Mislim da je riječ o nekakvom segmentu u našem kulturnom naslijeđu. Ali drugi dio koji meni smeta, što možda baš ne možemo promijeniti preko noći, jesu institucije koje potiču pasivnost, čak institucije koje po mom sudu imaju nevjerojatnu odgovornost za to da naši znanstvenici ne budu pasivni. Te bi se institucije 
trebale aktivno boriti za humanističke znanosti u svakom smislu koji smo danas spominjali. Institucije treba na neki način protresti. Ja ne znam odgovor kako se to točno radi. Ja na ovome, na čemu mogu, mogu pokušati djelovati na određene osobe ili skupinu osoba, ali to bi trebalo biti puno šire i jače. I medijski popraćeno jer kod nas je svetinja ono što piše na portalima.

Davor Dukić: Kada bismo pokušali s ovim okruglim stolovima izaći malo izvan djelokruga ovog našeg časopisa i poticati, odnosno provoditi nekakav društveni angažman... Ovo je večeras dobra posjećenost, obično je to manje, komorno društvo ljudi koji se poznaju i znaju tko što misli... Ipak, čini se da čak i na ovo vaše pitanje, kolega Perušiću, teško da možemo odgovoriti, opet bismo morali pitati nekoga sa strane, a akademkinja Žic Fuchs na nj možda može bolje odgovoriti zato što češće boravi vani i ima više mogućnosti uspoređivati.

Milena Žic Fuchs: Dobar dio dana pišem mailove i tekstove od kojih bi se neki znanstvenici zgrozili jer ti tekstovi nemaju direktne veze sa znanošću. Ja sam mogla imati ne znam kakvu bibliografiju, ali sam osjećala 136 intuitivno, ili kako god hoćete, da se želim posvetiti i drugim pitanjima. Kao prvo, imala sam podosta uspjeha, to moram reći, inače čovjek ne bi imao motivaciju, ali možemo reći da je urodilo plodom. I to pod navodnicima u malim stvarima, kao egiptologija u Francuskoj do, evo, humanističkih i društvenih znanosti u službenim dokumentima Europske komisije. To ne pada s neba. Veliki trud je potreban. Jutros jedna priča sa Sveučilišta. Ja se isto tako vrlo intenzivno bavim paneuropskim infrastrukturama, to je drugi dio moje angažiranosti. Nikako ne mogu dobiti da se nađu na Sveučilištu, govorim doslovce o svim sastavnicama, da se organizira tribina, okrugli stol (neka nazovu to kako god hoće) o paneuropskim infrastrukturama. To nisu mikroskopi, i ne govorim o kapitalnoj opremi, nego o nevjerojatnim bazama podataka za sve naše struke. Uz veliku muku uspjela sam uvesti Hrvatsku u CLARIN, to je jezikoslovna istraživačka infrastruktura. Strašno, ali trebalo je šest godina prepirki. Dok nisam jednoj vrlo visoko pozicioniranoj osobi rekla da je čekaju sve naslovnice hrvatskog tiska, da ako su u CLARIN-u svi jezici Europe, a potom i kineski jezici i četiri južnoafrička - a hrvatski kao europski jezik nije... netko mora odgovarati za to. Nekim čudom, odmah smo dobili novac. Čini se da koji put treba malo zagrmjeti.

Davor Dukić: Hvala. Pokušavam zaključiti, radimo već skoro tri sata. Nadam se da će transkript okruglog stola koji će proći autorizaciju 
biti inspirativan onima koji će ga čitati. Mislim da se pokazalo da je ova tema vrlo široka, vrlo kompleksna. Razgovarali smo o interdisciplinarnosti - taj je pojam u naslovu - ali spominjale su se i transdisciplinarnost i multidisciplinarnost. Ja sam malo pogledao prije okruglog stola kako se ti pojmovi definiraju na mjestu gdje bi trebali biti precizno definirani, a to je Struna, internetski portal Instituta za hrvatski jezik i jezikoslovlje. I tamo su definicije precizne, prema jedinstvenom kriteriju, prema različitim metodama koje se primjenjuju. Ovdje smo čuli druge definicije [M. Žic Fuchs], koje polaze od postojećih klasifikacija znanosti i znanstvenih područja. Uvjerljive su i jedne i druge premda su vrlo različite. I unatoč tim značenjskim diskrepancijama mi se ovdje dobro razumijemo, dobro znamo tko o čemu govori i zato mislim, iako ne možemo ponuditi neko sustavno znanje jer je prekompleksno, da će ovaj prilog našim čitateljima biti inspirativan, kad već ne može biti društveno utjecajan. Hvala svima što ste došli i stvarno dugo bili večeras. Nadam se da je i vama bilo zanimljivo. 